Portland State University

PDXScholar

Spring 6-1-2015

\title{
Democratizing the City Through the Colonization of Public Space: A Case Study of Portland Food Not Bombs
}

Trent Adam Saari

Portland State University

Follow this and additional works at: https://pdxscholar.library.pdx.edu/open_access_etds

Part of the Politics and Social Change Commons

Let us know how access to this document benefits you.

\section{Recommended Citation}

Saari, Trent Adam, "Democratizing the City Through the Colonization of Public Space: A Case Study of Portland Food Not Bombs" (2015). Dissertations and Theses. Paper 2393.

https://doi.org/10.15760/etd.2390

This Thesis is brought to you for free and open access. It has been accepted for inclusion in Dissertations and Theses by an authorized administrator of PDXScholar. For more information, please contact pdxscholar@pdx.edu. 
Democratizing the City Through the Colonization of Public Space: A Case Studey of

\title{
Portland Food Not Bombs
}

\section{by}

Trent Adam Saari

A thesis submitted in partial fulfillment of the requirements for the degree of

\author{
Master of Science \\ in \\ Sociology
}

Thesis Committee:

Amy Lubitow, Chair

Daniel Jaffee

Robert Liebman

Portland State University 2015 


\begin{abstract}
The implementation of neoliberal economic and political policies is often touted as a way to increase overall individual well-being and freedom. While these policies may benefit those already wielding economic security and political power, marginalized populations often bear the negative cost associated with such policies. As deregulation and privatization increases, social safety nets and social spending are dramatically reduced. At the local level, liberalization has resulted in increased surveillance and regulation of public space. Organized resistance to global corporatization and increased economic and political marginalization has occurred across the globe. Resisting neoliberalism is complex as the adaptability of the state and capital requires an adaptive form of resistance. Portland Food Not Bombs provides an empirical example of an oppositional social movement organization that resists neoliberal logic and reclaims public space for collective use by serving free meals. This case study includes participant observation of both Portland FNB chapters conducted at chapter specific meal preparation and serving sites. It also includes ten interviews with individuals who are heavily involved with the SMO. Publicly available documents such as Facebook pages, chapter specific websites, and the FNB website provided important contextual information as well. This study finds that the organizational structure of Portland FNB lends itself to more democratic practices and ideals, coinciding with the values of the respondents. Through transparent, consensus decision-making and a resistance to formal leadership, Portland FNB facilitates a different form of political engagement. By using public space, Portland FNB temporarily alters the physical urban environment by socially
\end{abstract}


constructing a more inclusive space, emphasizing that collectively using public space, is indeed a human right. Portland FNB seeks to create a more just society within the existing institutional framework, while rejecting practices associated with 501(c)(3) organizations and other mainstream SMOs. 
Abstract

List of Tables vi

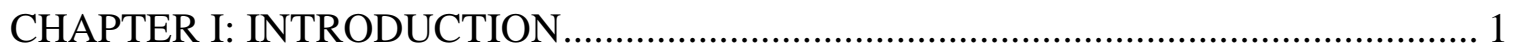

Research Setting ...........................................................................................................................5

CHAPTER II: LITERATURE REVIEW ……………......................................... 9

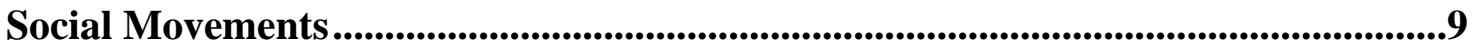

New Social Movement Theory ................................................................................11

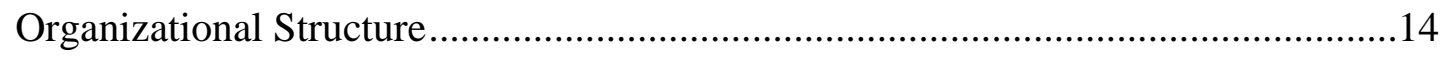

The Social Construction of Space ......................................................................................19

Alterations to the Urban Environment.................................................................22

Conclusion..................................................................................................................................26

CHAPTER III: RESEARCH METHODS AND DESIGN_............................................. 29

Framing the Case ...................................................................................................................29

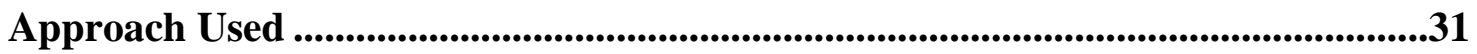

Data Collection ................................................................................................................32

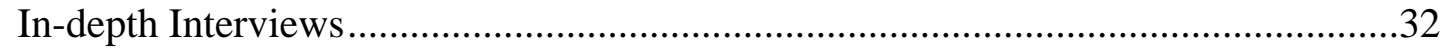

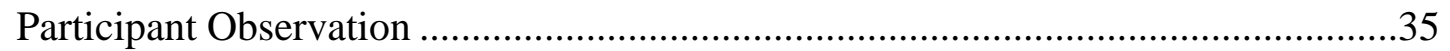

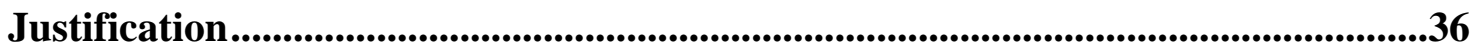

Data Analysis ..................................................................................................................37

Advantages and Limitations..................................................................................................37

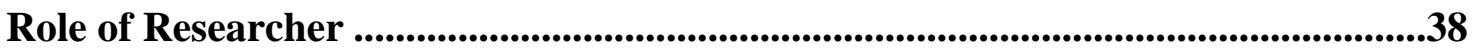

Conclusion.................................................................................................................................39

CHAPTER IV: THE VALUES AND STRUCTURE OF PORTLAND FNB .................. 40

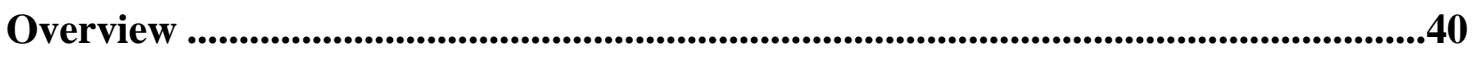

Food Not Bombs as a Social Movement Organization.....................................................41 
“The SWAT Team of Radical Cooking”: Portland Food Not Bombs.......................45

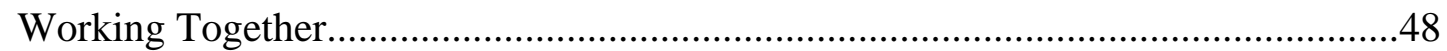

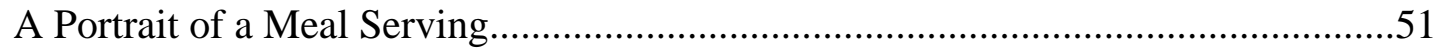

Assuming the "Lead": Leadership within Portland FNB ....................................52

Creating Communities with Food, Not Bombs...............................................................58

Attempting to Spread an Alternative Model..........................................................61

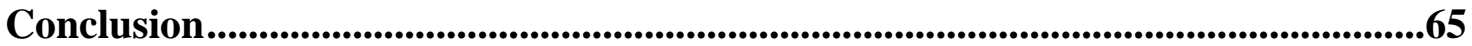

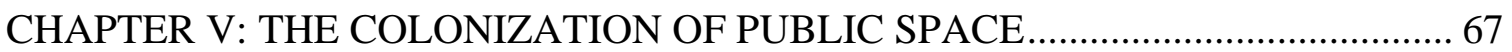

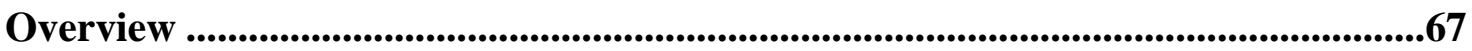

Survival in the City: Space and Place in a Neoliberal Era..................................68

Filling in the Gaps: Providing Healthy and Nutritious Food................................70

A City Regulated: The Retraction of Public Space.....................................................72

The Experience of the Downtown Cell: The Efforts of FNB to Reclaim Public

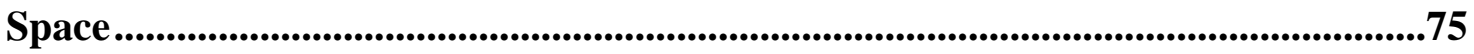

The Struggle of Making the Meal Serving Visible..................................................78

An Interstitial Existence: Stuck Between the City and a Private Entity.................81

Creating a Community through the Colonization of Public Space ........................83

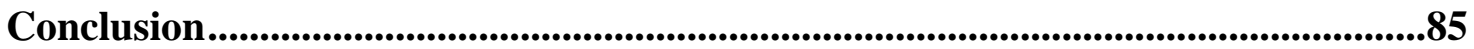

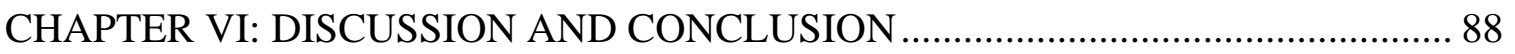

Values Associated With Portland FNB ............................................................89

Structure of Portland FNB ................................................................................91

Strategy and Tactics..............................................................................................................992

The Use of Public Space in Prefiguring Society ......................................................93

Implications...........................................................................................................................95

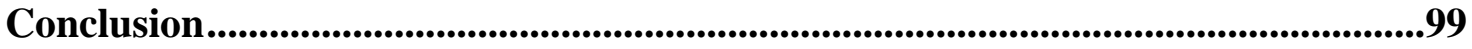

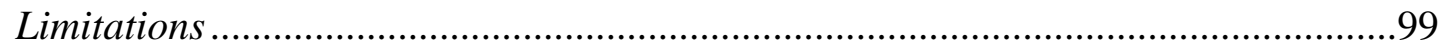

Suggestions for Future Research..................................................................100

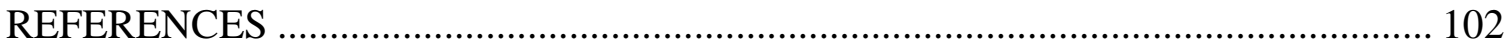




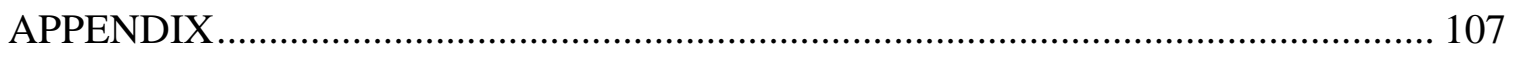

Appendix: Interview Guide for Portland FNB Participants................................107 
List of Tables

Table 1. Portland FNB Questionnaire Data 34

Table 2. Basic Characteristics of Mainstream and Oppositional SMOs 41

Table 3. Portland FNB Questionnaire Data 47

Table 4. The Core Tasks of FNB 49 


\section{CHAPTER I: INTRODUCTION}

Within Portland, Food Not Bombs intends to serve meals to marginalized populations, specifically the homeless population. Therefore, in this case, it is necessary to provide an overview of homelessness within Portland. According to the 2013 Point in Time Count, there were approximately 15,917 homeless individuals within Multnomah County. Of these 15,917 individuals, 1,895 were unsheltered. This means that those individuals were either sleeping in abandoned buildings, vehicles, or other "unsheltered" locations. This number is most likely an underestimation as unsheltered individuals are often difficult to make contact with. A disproportionate percentage of those unsheltered, are people of color (38\%). In comparison, people of color comprise $29 \%$ of individuals residing within Multnomah County. Although the point-in-time count covers Multnomah County, the vast majority of homeless individuals most likely reside within the city of Portland. Among major U.S. cities, Portland has the third highest rate of chronically unsheltered homeless individuals (Griffin 2015). The marginalization of the homeless does not exist within a vacuum and rather it can be foregrounded within a broader, neoliberal political and economic climate.

Neoliberalism can be understood as the implementation of political and economic policies that reinforce the notion that individual well-being rests upon the expansion of entrepreneurial freedoms (Harvey 2005). The state is often complicit in ensuring these policies are actualized through the protection of private property, liberalizing markets, etc. Neoliberalism gained traction in the late 1970’s, early 1980's as a response to a prolonged global recession (Brenner and Theodore 2002). The existence of neoliberalism is often contradictory as liberalization is a dialectical process that involves competing 
institutional frameworks, various social actors, and effects manifesting at different scales (global, national and local). While neoliberal policies may be touted as expanding freedom, economic security, and overall well-being, the reality is often much more complex.

The individualistic character of neoliberal policies and the mechanisms of liberalizing often heavily benefits those with established political and economic power, while the social cost is often shifted to marginalized populations. As the implementation of neoliberal economic and political policies "create" a market-oriented institutional framework, they simultaneously “destroy” social safety nets, shrink public sector employment and the use of state apparatuses that are shielded from the public. Moments of "destruction" coincide with moments of "creation" as the dismantling of safety nets and protectionist policies coincide with the adoption of neoliberal policies.

For example, as laws protecting workers are dismantled, new legislation promoting "labor flexibility" may be adopted. Other examples of these tenuous situations include the dismantling of protectionist trade policies in favor of global liberalized trade deals and the increased ability of supranational organizations to oversee global transactions in favor of nation-state oversight (Brenner and Theodore 2002). Furthermore, it has been suggested that these policies result in a loss of democratic participation and input from citizens at the local level (Purcell 2002). As the state functions to further the interests of capital, transparent decision-making and inclusivity in the decision-making process are often foregone. The negative effects of neoliberal policies have not gone unattested as illustrated by the following examples. 
Within the last two decades, movements such as the Zapatista uprising in the state of Chiapas (Mexico) and protests in Seattle directed at the World Trade Organization have illustrated the unpopularity of neoliberal trade policies. More recently, austerity measures in nations across the globe have been met with resistance in the form of protests and legal challenges. Recently in Spain, the 15 May movement or Indignados, practiced "anti-politics" occupying public squares, universities, and hospitals across the country in opposition to bank bailouts and a widely present feeling of not being adequately represented politically. As the state was viewed to be serving the interest of capital regardless of party, people rejected mainstream politics and engaged in mass protests (Stobart 2014).

In Greece for example, the privatization of public goods such as water, has been challenged by citizens often with the support of court systems (Kitsantonis 2014). The high level of opposition to neoliberal policies is apparent at the national level as the antiausterity party Syriza won an election for the first time in 2015. The party’s leader, Alex Tspiras ran on a platform seeking debt forgiveness and roll-back of austerity measures (Forelle, Stamouli and Granitsas 2015). Although the specific details are different, the resistance to austerity in Greece is reminiscent of the tumultuous situation in the early 2000's in Cochabamba, Bolivia as privatization of public goods is once again being pushed by supranational institutions as a way to reduce government spending. On a recommendation from the World Bank, Cochabamba's water supply was privatized resulting in extraordinarily high rates. Protests were met with severe state resistance but were ultimately successful in rolling back the privatization (Shiva 2002). 
While the implementation of neoliberal economic and political policies shape interactions at a global level, the WTO protests and water wars in Cochabamba allude to the role of the city in an ever-changing economic and multi-scalar political landscape. Increasingly, the city has been touted as a site for neoliberal experimentation (Brenner and Theodore 2002). At the local level, neoliberal political and economic policies often result in the contraction of public space and increased surveillance. Stringent regulation and increased surveillance often affects society's most marginalized populations severely. For example, numerous U.S. cities have passed laws restricting individuals from sharing food with the homeless. This restriction coincides with the notion that cities are sites for capitalist accumulation and elite consumption, rather than arenas for collectively meeting the social needs of all.

Most importantly, within the context of FNB, is the ability of individuals to access public space and share food with homeless individuals. Cities often use subjective regulation in order to discourage and outlaw such action. According to the National Coalition for the Homeless (2014), cities restrict food sharing through means such as requiring a permit to use public property, forcing individuals and organizations to comply with food-safety legislation, and through less direct means such as harassment from businesses or neighbors. Within Portland, FNB has experienced resistance in the form of each strategy outlined above. Despite the resistance Portland FNB experiences in occupying and repurposing public space, the organizational structure and the act of reclaiming space for collective use are forms of symbolic resistance to the further marginalization of already vulnerable populations and the broader trend of liberalization. 


\section{Research Setting}

Portland FNB is a non-hierarchical, horizontally structured, grassroots organization. Individuals are all volunteer and are not compensated for their time, energy, or effort. There is no identifiable leadership and the organizational structure resists formal titles and positions. This coincides with broader anarchist principles and more specifically, strands of anti-authoritarianism. Within Portland, there are two FNB cells that operate autonomously. At times, the cells engage in collaborative efforts for activist events such as social forums, marches, etc. but, the day-to-day operation of each cell is independent of the other. Each week, both cells engage in direct action by serving free meals in public space. One cell serves in close vicinity to a public transit station and the other serves at a popular public park within Portland. Portland FNB relies upon repurposing produce that participants gather in order to create dishes for the meal servings. Preparation space is typically "lent” by a participant that is heavily involved or obtained through the extended social network of Portland FNB. Participation within the organization is fluid with individuals freely entering or exiting the organization.

The mission of Portland FNB is "To help build a stronger, healthier, community by working together creatively, without hierarchy or violence to meet the nutritive needs shared by every person on earth...without regards to their means or 'status'.” The mission statement emphasizes inclusivity, egalitarian relations, and non-violence. The organizational model of Portland FNB is reflective of these values and principles as well as others. In fulfilling the organization's mission, Portland FNB radically alters the urban landscape, asserting that the use of public space is a collective right. 
This specific case study of Portland FNB is guided by the following research questions: 1) What is the organizational structure of Portland FNB?, 2) Do Portland FNB respondents understand the organizational structure of FNB to be an alternative organizational model and if so, how?, and 3) How is Portland FNB's use of public space reflective of its organizational dynamics and principles?

In this study, I utilize qualitative interviews and participant observation to argue that Portland FNB exemplifies how asserting a right to the city can directly oppose larger neoliberal forces. Specifically, I suggest that through organizing horizontally, Portland FNB creates a space where individuals can directly engage in more democratic practices. This organizational model is then extended to the public sphere via proactive colonization of public space. By serving free meals in public, Portland FNB resists marginalization and reclaims public space for collective use. This reclamation is not without resistance from city and private entities, highlighting the volatility of the urban landscape. As pubic space is contracted and subject to increased surveillance and regulation, Portland FNB proactively engages in the process of defining and redefining what is considered public and who can occupy it. Portland FNB asserts the city is an arena for democratic experimentation, not a site for the implementation of neoliberal economic and political policies.

\section{Chapter Overview}

In the following chapter, I review literature related to social movements and particularly New Social Movement theory, organizational structure, and the social construction of space. This will provide a contextual background in which Portland FNB can then be situated. After reviewing the bodies of pertinent literature, I then introduce 
my research questions. The research questions will be immediately followed by the research methods and design that was utilized in order to answer the research questions. The strengths and limitations of the research methods will be discussed, as will the political and ethical issues associated with conducted qualitative research.

After introducing my research methods, I will present my findings. These are organized into two separate but related chapters. The first chapter will focus on the organizational structure of Portland FNB. As the organizational structure is reflective of values and larger principles, what these values and larger principles entail, will be explored as well. The second findings chapter will discuss how this organizational model is extended to the public sphere and how this extension is a form of resistance to encroaching neoliberal policy. Finally, the discussion and conclusions chapter will reiterate the findings in reference to the research question while also indicating the specific limitations of my study. The final chapter will conclude with suggestions for future research that may be conducted along the same theoretical lines and with attention to similar areas of interest.

In totality, I will demonstrate that the organizational structure of Portland FNB constitutes an alternative organizational model, in comparison to the state and other topdown bureaucratic structures. This helps to create a space in which participants can practice and experiment with democracy, egalitarianism, anti-authoritarianism, transparency, etc. Formal leadership is replaced by task-oriented leadership which has the possibility to be undertaken by all willing participants. The colonization of public space asserts that the presence of public space and the ability to collectively use it, is indeed a right. By serving free meals in public space, Portland FNB resists marginalization and 
increased regulation of public space. This study provides insight into how public space is contested and the larger social forces behind increased regulation and surveillance of public space. As public space is a common good that may often go unthought-of, this research study sheds light on the how the struggle to reclaim public space has broader implications for organizations and movements attempting to create a more just and equal society. 


\section{CHAPTER II: LITERATURE REVIEW}

In order to effectively discuss the findings from a case study of Portland FNB, part of a larger anarchist social movement, I begin with an overview of social movement literature in order to place FNB within a broader historical and conceptual framework. This includes not only focusing on the "type" of social movement Portland FNB can be characterized as, but also how values influence the organizational structure, and how the structure determines the tactics. As Portland FNB regularly engages in direct action, I also survey literature pertaining to the alteration of urban space in service of democratic ideals.

In this chapter, I review the foundational social movement literature, including literature on relevant social movement scholarship, with particular emphasis on New Social Movements. I also review literature focusing on the social construction of space within pre-existing physical urban and public space. As Portland FNB manipulates public space in service of democratic ideals, included literature adheres conceptually to the manipulation of existing space in service of larger democratic ideals. The relationship between these bodies of literature and Portland FNB will be clear throughout the study.

\section{Social Movements}

A social movement organization is defined as a complex, or formal, organization which identifies its goals with the preferences of a social movement or a countermovement and attempts to implement those goals (McCarthy and Zald 1977). The preferences of social movements vary from movement to movement and may be specific (i.e. voting rights), or broad in scope. Buechler defines social movements as, "opinions or beliefs that represent preferences for change in society” (2000:36). Social movement 
organizations in addition to attempting to implement their goals which align with a social movement, must also simultaneously further the interests of its individual members in order to maintain the organization's existence. As an incentive for individuals to remain active in the organization, the disbursement of non-collective goods is necessary (Olson 1965:16). It is important to note that the social movement organizations Olson is focused upon are hierarchal in structure (labor unions, national governments, etc.) and a more "market-based” or "rational” approach is employed when looking at collective action. It is necessary to mention that Olson's position regarding the "free-rider" dilemma does not go unchallenged by new social movement theorists.

Social movement organizations are grouped into social movement industries. These organizations typically have similar goals and thus end up competing with one another for resources. Formal SMO's (social movement organizations) often become bureaucratic and professionalized as they must engage in fundraising and other resource gathering activities. These SMO’s are dependent upon outside actors (wealthy elites, etc.) to a greater degree than loosely structured SMO’s (Buechler 2000:36). In the 1970’s, resource mobilization emerged as the dominant theoretical framework for examining social movements. McCarthy and Zald refuted the popular notion that common grievances and ideologies were sufficient for engaging in collective action but rather argued that activity towards a goal was dependent on the organization's control of resources in the form of legitimacy, money, facilities, and labor (1977:1220-1221). Along the same line of theoretical thought, McAdam (1982) added a political process to the resource mobilization perspective (McCarthy and Zald 1977). McAdam argued that the possibility of collective action directly hinged upon the structure of political 
opportunities. In McAdam's model, the role of the activist base in terms of power is given more attention as the degree to which the power relationship between activists and those in authority positions is in balance is focused upon. McAdam also identified two more factors that heavily influenced the possibility of collective action; the cohesiveness and strength of the activist organization and the belief that direct action can effectively change what is seen as an illegitimate social order (Buechler 2000:37). The synergistic relationship of these three factors can then be used to predict the occurrence of collective action in the form of a social movement.

That being said, resource mobilization theory does not exist without critique from other scholars. Common critiques of resource mobilization include the minimization of the role of grievances and conceptual factors, the overemphasis on formal organizations at the expense of informal and decentralized networks, and the absence of cultural processes within collective action (Buechler 2000:37-38). New social movement theory emerged in the 1980's, both of which address areas which resource mobilization theory overlooks (Buechler 2000:40) and thus is the "best" approach to take when exploring and understanding a contemporary social movement such as FNB.

\section{New Social Movement Theory}

New social movement theory moves away from utilizing a traditional class-based approach to explore and understand collective action as everyday life is becoming increasingly regulated (Buechler 2000:46). In advanced capitalism a NSM (new social movement) theoretical approach becomes especially useful as control and domination is not only limited to the sphere of material production, but social production (social relations and social systems) as well. Melucci argues that due to ever-expanding systems 
of science and information, personal identity has become a site for collective action as individuals collectively vie for the right to define themselves (1980:218). Similarly, Habermas argues that in advanced capitalism the life world is increasingly colonized as money and power dictate decision making, thus replacing communicative rationality. Communication becomes rational as individuals must defend their position in a process that strives to achieve mutual understanding and agreement (Buechler 2000:83-84). Buechler notes the welfare state in advanced capitalism is a prime example in which monetary and bureaucratic forms of control have replaced open communication, thus resulting in the dwindling possibility of opposition as class structure becomes obscured (2000:84-85). These definitions, although slightly different, capture the defining characteristic of advanced capitalism; the overwhelming degree of domination and control that dictates everyday life.

Classifying "new social movement theory" is difficult as there is not an actual agreed upon theory per say but, rather a multitude of theoretical approaches exist. Buechler notes that there are a number of themes, any of which, may be present in a particular "new" theoretical approach that is undertaken. They are as follows: 1) the existence of a model of societal totality that serves as a contextual background for collective action; 2) the existence of a causal link between this totality and collective action; 3) a diffuse social base as various identifies may serve as mobilizing statuses in the place of a traditional class-based identity; 4) the necessity of a socially constructed collective identity; 5) the belief that everyday life is political; 6) emphasis on postmaterialist values; 7) a focus upon cultural and symbolic resistance and finally; 8) the establishment of a loosely structured organizational form (2000:45-48). From the list of 
themes above, it is evident that "new social movement theory" is more of an umbrella term which encompasses varying approaches taken to explore contemporary social movements and social movement organizations.

Similar to Buechler, Melucci also identifies themes that are characteristic of contemporary social movements, although a great degree of overlap does exist as Buechler's list is a compilation. Melucci notes that as everyday life is politicized, resistance to domination can become stigmatized as a deviant form of behavior (1980:219-220). This can result in difficulty for new social movements in terms of identifying the “opposition” and planning movement activity accordingly. This is especially evident in Gamson’s (1989) study of AIDS activism. Gamson captures the difficulty that the nation-wide coalition ACT UP (AIDS Coalition to Unleash Power) experienced in terms of engagement in collective action. As there are a multitude of potential targets, (state, media, corporations, etc.) discussions of those specifically targeted by the organization’s actions rarely occur thus the organization’s actions appear disjointed at times (1989:35). This example illustrates just one difficulty contemporary social movement organizations must deal with.

Another important aspect of contemporary social movements that Melucci highlights is, favoring of direct participation over that of formal representation. This results in organizational structures that tend to be anti-authoritarian and non-hierarchical (1980:220). The diffusion of power outward rather than upward attempts to ensure that individuals' rights to their identity remain unimpeded. At the transnational social movement level, this diffusion of power is characteristic of global justice movements as new information technology has resulted in the preference for decentralized network- 
based organizational forms (Juris 2005a:341). Activists internalize what Juris calls the "cultural logic of networking”, which is comprised of a distinct set of social and cultural components. Castells identifies these components as being: 1) the building of horizontal ties and connections among diverse, autonomous elements; 2) the free and open circulation of information; 3) collaboration through decentralized coordination and directly democratic decision-making and 4) self-directed or self-managed networking. This logic can then serve as a model to emulate by participatory democratic organizations at the local, regional, and global scale (Juris 2005a:342).

\section{Organizational Structure}

Scholars have noted that the symbolism of organizational form and the internal structure of the organization influences organizational identity and the ability of the organization to act toward its goals (Clemens and Minkoff 200:158). As illustrated above, new social movements, in this case FNB, often value a non-hierarchal and more democratic organizational model. Although radical networks may value forms of direct/participatory democracy and a more horizontal structure, this does not ensure a condition of egalitarianism as informal hierarchies may develop unintentionally (Juris 2009:216).

This is evident in the case study of Indymedia Australia, which is part of the global online news network Indymedia. Hierarchies formed around editorial collectives as the institution of a features column, required an editing process. During this process, individuals may act without consulting other members. A visible structure helps to ensure accountability and reifies operating non-hierarchically (Pickerill 2007:2669). Despite the reality that non-hierarchal organizational forms do not completely eradicate uneven 
power relations, the adoption of anarchist principles by radical global justice activists (Juris 2009:215) and other activist networks (Pickerill 2007) illustrate an overall preference for political and social equality within organizations, networks and, movements alike.

Juris argues that "anarchism" is often misunderstood to mean disorder when in actuality, organization comprised of grassroots participation from the bottom, is a key tenet in any thread of anarchism (2009:215). Similarly, David Graeber notes that social movement organizations that incorporate anarchist principles are not without ideology, but rather their attempts to "reinvent democracy" through production of new organizational forms is an ideology in itself (2002:11). Through democratic practices that are fully participatory, radical social movement organizations such as, Fitzgerald and Rodgers, label these specific types of contemporary SMOs which allows each individual member to hone their leadership skills (2000:579).

In recent contemporary social movements, such as Occupy, participatory democracy has been practiced through general assemblies which allow each individual to have a voice within the organization. However, it should be noted that constant efforts to address class and racial inequality are needed through coalition building and antioppression workshops as the inclusion of the working class and racial/ethnic minorities is a central challenge of the Occupy movement (Juris 2012:271-272). Dellacioppa, Soto, and Meyer argue that general assemblies, specifically in the case of Occupy LA, have allowed for social differences such as class, race, and gender to be acknowledged and discussed more openly, resulting in a new strategy for consciousness building (2013:415). 
In addition to the incorporation of egalitarian practices, radical social movements often have much smaller membership bases than traditional SMOs. Participants in such social movement organizations have characterized them as being "member free” (Juris 2005a:350) as individuals do not officially “join” as “membership cards” don’t exist (Fitzgerald and Rodgers 2000:580). Participants have also noted that having a small membership base that is not preoccupied with expanding the membership roll, allows individuals to avoid potentially having to comprise one's ethics in order to sustain the organization (Fitzgerald and Rodgers 2000:579).

At times, this adherence to a non-hierarchal organizational form and the accompanying principles, can become a source of friction. In 2000 at the World Social Forum in Porto Alegre, Brazil, the Movement for Global Resistance (MRG) refused to become a member after being exclusively invited to by the International Committee. Other grassroots organizations were invited to observe the forum, but were not extended membership as MRG was. MRG issued a statement decrying the process for being "undemocratic" and "top-down". The statement went on to further describe how the process was simply incompatible with the new form of politics that are characteristic of networkbased organizations (Juris 2005b:260). Similarly in 2002, Indymedia also faced a similar dilemma as Indymedia Argentina "blocked" the consensus process as it refused to agree that Indymedia accept a \$50,000 Ford Foundation Grant, which would have helped fund an international conference, on the grounds that accepting the grant would violate Indymedia's principles of egalitarianism (Pickard 2006:315-316). These examples indicate that sustaining radical democracy is an ongoing process that is not without internal difficulties or competition from traditional bureaucratic organizations. 
These actions at the local and global scale may lead one to believe that more radical SMOs can only exist in isolation, at the very fringes of any social movement, however this is not necessarily the case. Radical SMOs seek larger structural change as the "capitalist system" or "power structure" is identified as the root of societal problems (2000:581). In their exploration of 13 SMOs, representing seven different social movements in Vancouver, British Columbia, Carroll and Ratner (1996) concluded that activists who framed injustice within a "political economy frame" tended to be more engaged in cross-movement activism and have more cross-movement ties to other activists. "The political economy frame" states that injustice stems from exploitation as power is concentrated and domination is systemic, structural, and institutionalized (1996:609). This case illustrates that the potential for network-building and crossmovement activism does exist for radical SMOs as similar framing techniques exist throughout various social movements and the SMOs that represent them.

\section{Prefigurative Politics and Tactical Repertoires}

Contemporary social movements' goals are described as being emancipatory, rather than being reformatory, as they seek fundamental structural change, rather than focusing on political change through legally sanctioned means (Fitzgerald and Rodgers 2009:575). Many contemporary social movements such as FNB, engage in what is called "prefigurative politics", in which their organizational forms and activities, embody and sustain the desired configuration of a future society (Breines 1989:6). Buechler defines prefigurative politics in association with the New Left, as the way that "the movement organized its activities in a manner that prefigured the broader cultural values and social relations that it was seeking in a transformed society” (2000:204). 
Engagement in "prefigurative politics" has an impact on contemporary social movements' choice and use of protest tactics. Taylor and Van Dyke define protest as the collective use of unconventional methods of political participation to try to persuade or coerce authorities to support a challenging group’s aims (2004:263). Contemporary social movements typically engage in direct action. Direct action methods of protest may include strikes, sit-ins, free speech campaigns, boycotts, mass meetings, and demonstrations (Fitzgerald and Rodgers 2009:583). Juris notes that direct action is not only strategic but it is also symbolic as it expresses the desired values of the future society contemporary social movements are attempting to implement (2009:220). Although it may seem as if an infinite number of protest possibilities exist, scholars often argue that tactics of protest are often predictable as protesters utilize preexisting protest tactics (Taylor and Van Dyke 2004:264). However, a wide range of specific forms of protest may be utilized by social movement actors. Therefore, Taylor and Van Dyke place specific protest tactics within a broader conceptualization of protest tactics used in "episodes" of collective action. The scholars define tactical repertoires as "interactive episodes that link social movement actors to each other as well as to opponent and authorities for the intended purpose of challenging or resisting change in groups, organization, or societies” (2004:266). Tactical repertoires consist of three criteria: 1) contestation; 2) intentionality; and 3) collective identity. Contestation acknowledges that tactical repertoires are sites in which symbols, identities, etc. are used to challenge institutionalized power relations while intentionality refers to a level of consciousness that involves strategic decision-making in resisting domination. Finally, 
collective identity refers to the notion that engaging in protest can also help to construct solidarity between activists within the organization itself (2004:269-270).

Tactical repertoires are not chosen based on strategy alone, but also upon ideological fit, level of compatibility with the social actors' collective identities, and how well they provide meaning and motivation for collective action (Taylor and Van Dyke 2004:276-277). A prime example of this is how tactics were employed in protest of the International Monetary Fund and World Bank in Prague in September 2000. Various sectors of the city were "color-coded" indicating the use of a specific protest tactic. These tactics ranged in their level of direct confrontation with authority figures (political theater to more militant actions). This specific spatial tactic reinforces the ideological importance of operating horizontally, while also being successful in a strategic sense (Juris 2009:219). Tactical repertoires allow for a multitude of specific protest tactics to be explained in a broader framework, thus allowing for comparative processes to undertaken.

\section{The Social Construction of Space}

Increasingly, sociologists and geographers alike, have placed a great deal of importance upon the relation of social movements and social movement organizations, to spaces, public and private, open, and contested. Access to space and the ability to use it is not only necessary to engage in forms of collective action such as protest, but it also takes on an important role in social movement building (collective identity, etc.) as space is often socially constructed. Evans and Boyte define free spaces as "settings between private lives and large scale institutions where ordinary citizens can act with dignity, independence and vision.” (1986:17). Polletta notes that within social movements, “free 
spaces" help facilitate the distribution of identities, frames and protest tactics while "free spaces” may also serve a cultural resource if they are the result of previous protest (1999:4). For prefigurative social movements, “free spaces” may help to sustain motivation and membership within the movement. It also important to note that these "free spaces" are created during or after mobilization occurs in such movements (1999:12).

At the global scale, Juris notes that "network based politics involves the creation of broad umbrella spaces, where diverse organizations, collectives and networks converge around a few common hallmarks, while preserving their autonomy.” (Juris 2005a:353). Routledge (2003) has conceptualized what are called “convergence spaces” to further understand social relations within grassroots globalization networks. "Convergence spaces" consist of four main themes: 1) they are comprised of diverse social movements which have collective visions; 2) processes of facilitation and interaction tend to be uneven; 3) facilitate action at various scales; and 4) they are comprised of contested social relations. The difficulties in social relations arise primarily from the multi-scalar nature of grassroots globalization networks which must operate at both a local level and global level. Larger goals may be left unrealized as threats at the local level may require those local organizations' complete attention or uneven access to resources may result in uneven power relations (2003:345-346).

At the regional level, Hodkinson and Chatterton (2006) have examined the rise of social centers in the United Kingdom in the late 1990's-early 2000's, which attempt to serve as stable physical spaces for activists from various movements to network with one another, congregate, etc. These social centers represent the potential for activist nodes to 
spread from community to community. The critique social centers face is the possibility they may become "activist hubs" and thus the reclamation of abandoned buildings may solely be an act of symbolism, rather than the beginning of a prolonged state of resistance (2006:314). Pickerill and Chatterton (2006) identify social centers as examples of what they call “autonomous geographies”. Autonomous geographies are defined as "spaces where people desire to constitute non-capitalist, egalitarian and solidaristic forms of political, social, and economic organization through a combination of resistance and creation.” (730).

In order to completely grasp this definition of "autonomous geographies”, a conceptualization of autonomy is necessary as it provides further contextual information. Pickerill and Chatterton conceptualize autonomy in five ways: 1) it is highly contextual and historically specific; 2) as a temporal-spatial strategy it exists between globalization and localization (operate primarily at the local level but seek large scale change); 3) autonomy exists interstitially; 4) autonomy is an act of resistance and creation; and 5) revolution of everyday life is a praxis (essentially this is engagement in prefigurative politics) (2006:732-739). Other scholars have also provided conceptions of autonomy. Böhm, Dinerstein, and Spicer (2010), conceptualize autonomy by identifying three specific strands: 1) beyond capital; 2) beyond the state; and 3) beyond development. Autonomous production beyond capital, refers to social production in which profit is not the primary driving force, but rather the desire to create space, information, etc. In advanced capitalism, the "state" is often ignored by contemporary social movements and the seizing of state power is not a primary goal of autonomous organizations. Finally, to move beyond development refers to the ability of nations, peoples and local communities 
to self-organize and self-determine within a post-colonial context. In this case, hegemonic power is resisted as it is responsible for producing global inequalities (2010:20-22).

Böhm et al. argue that complete autonomy can never be achieved as it exists and operates simultaneously alongside capital, the state and capitalist development without being subsumed by these actors. Therefore, autonomy provides the prolonged possibility that social change may occur (2010:27). Böhm et al., like Pickerill and Chatterton, recognize that the interstiality of autonomy or autonomous geographies is a defining characteristic as a dialectical existence is inescapable in advanced capitalism. Empirically this is evident by social centers being constantly under the threat of cooptation by the state. Social centers in the UK are under constant pressure to become "legal” (Hodkinson and Chatteron 2006:313). The push to become "legal” fractures the activist base as cooptation is seen as incompatible with being an "autonomous geography”. There are concerns that becoming "legal” will turn the social centers into yet another structure in which market-based values dominate. Yet, Pickerill and Chatterton also argue, that the interstitial existence of social centers may be one of their greatest strengths as they exist and operate as non-capitalist spaces with the potential to bring different social actors together within the larger capitalist sphere (2006:741).

\section{Alterations to the Urban Environment}

Autonomous geographies and convergence spaces manifest themselves in facilities at international forums and as illustrated above in social centers located within metropolitan cities such as London. These spaces are socially constructed yet, simultaneously and necessarily they are fixed locations within the physical or material 
environment as well. With this being the case, the physical environment and more specifically the urban environment, has become increasingly important in the discussion of contemporary social movements. As an economic system, capitalism is prone to crises as internal contradictions exist within the system. The most recent example would be the financial crisis in 2008 (Marcuse 2009:188). The inherent contradictions within capitalism are well documented and will not be discussed in detail here. However, for further discussion, it is important to note that increased privatization of public entities and adherence to market-fundamentalism is the contextual backdrop for discussion of the relationship between urbanity and contemporary social movements.

Purcell argues that governance of urban cities is being reconfigured in three ways: 1) it is being rescaled; 2) the focus of policy has moved away from the distribution of goods to competition; and 3) the functions that the state is traditionally responsible for are increasingly being privatized (2002:98). Rescaling refers to governance being shifted to supra-national institutions, such as the World Bank, as well as to sub-national institutions, such as municipal governments. Localities have increasingly become fixed upon the notion that they must compete in a global economy without nation-state support and thus, internal restructuring in the name of increased efficiency is taking place (2002:98-99). It is important to note that these reconfigurations occur in localities throughout the globally sphere due to the structure of the current neoliberal financial system.

Scholarly attention on movements calling for a radical transformation of how the urban is structured and operates, began with Henri Lefebvre. In 1968, Lefebvre conceptualized "the right to the city" as a term to encapsulate the complex dimensions of 
a desired radical transformation of the urban environment. However, Lefebvre (1968)

offered a very vague definition of his new concept which reads as follows, “...the right to the city is like a cry and a demand. This right slowly meanders through the surprising detours of nostalgia and tourism, the return to the heart of the traditional city, the call of existent or recently developed centralities” (158). From the beginning of the concept’s inception, scholars have interpreted and created varying definitions in order to capture the essence of what "the right the city” entails.

Purcell argues that Lefebvre conceived of space as not only physical space, but as a much more expansive entity that consisted of three different types of space: 1) perceived space; 2) conceived space; and 3) lived space. Perceived space is essentially physical space, while conceived space refers to mental constructions of space. Lived space is a culmination of the two and thus captures the interactive relationship between them (2002:102). Purcell further argues that for Lefebvre, the city is vastly different from the urban. The city is a reduction to economic relations (and perceived space), while the urban (lived space) is re-embedded social relations, such as democratic participation, etc. in everyday life (2014:148-149). David Harvey argues that the city is the most likely source of collective action due to economic conditions. Urbanization has been increasingly used to capture surplus capital, resulting in the dispossession and displacement of large numbers of people (2013:22). However, invoking the "right to the city” as framework to combat this situation, begs the question as to what one exactly aspires to achieve when invoking 'the right to the city” and what does achieving it look like. Harvey argues that the "right to the city" is "an active right to make the city different, to shape it more in accord with our heart's desire, and to re-make ourselves 
thereby in a different image.” (2003:941). Furthermore, he argues that the end goal should include increased democratic control over production and the use of surplus capital (2013:22).

These goals align with themes other scholars have identified as being fundamental to the mobilization of urban social movements. Castells proposes that urban social movements typically mobilize around three themes: 1) focus on demands for collective consumption; 2) the defense of a cultural identity that is tied to a specific territoriality; and 3) an emphasis on local governance (Castells 1983:xviii). However, achieving change associated with these themes is a contested process. One major challenge urban social movements experience is the inability or the unwillingness of state structures to balance the power of capital and increase local control (Purcell 2002:106).

Nicholls and Beaumont suggest that the relationship between the state and civil sectors of society is an area in which urban justice movements may experience difficulties that impede their chances for success (Nicholls and Beaumont 2004). Nicholls and Beaumont classify urban justice movements as multi-scalar movements, composed of various formal and informal organizations which have: 1) mobilized via material urban conditions; 2) rooted the movement's organizational structure at the urban level and 3) view the urban environment as a strategic site for mobilization and framing injustice (2004:120-121). Using three case studies: Los Angeles; Rotterdam; and Toulouse, Nicholls and Beaumont concluded that governance structure impacted the development of urban justice movements. In Los Angeles, a neoliberal governance structure gave way to successful mobilization as formal organizations had close ties with political elites and newer informal organizations were willing to engage in contentious political behavior as 
they had no established political ties. The cross-organization collaboration culminated in a successful mobilization of an urban justice movement while other governance structures (complex statist governance and authoritarian governance) were more constraining (2004:128-129).

In the case of Rotterdam, similarities to Buechler's evaluation of the bureaucratic welfare state arise. As political opportunities are more open, oftentimes organizations work to increase their sphere of influence rather than mobilizing a movement. In this way, the state is able to diminish the possibility of mobilization from the outset. While in Toulouse, smaller, informal organizations are in a subordinate position in relation to larger national organizations, thus engaging in collective action is most likely to result in severe repression (2004:131). In the case of Los Angeles, Nicholls and Beaumont make an argument that informal organizations may engage in more contentious political acts within physical space as loss in membership or damage to existing political ties are less of a liability (2004:131). This is an important aspect which cannot be overlooked as the engagement in contentious political acts relies upon the ability to utilize public space as a forum for visible resistance. Outside of mobilizing, engaging in contentious political acts is an important component of social movements. By occupying public space on a consistent basis, FNB regularly engages in contentious politics, confronting urban inequality.

\section{Conclusion}

As a contemporary social movement, Portland FNB offers an ideal opportunity to explore these varying dimensions that are associated with contemporary social movements in advanced capitalism. The literatures on new social movements, public 
space and urban social change are best-suited to support the themes of this case study. These literatures expand the theoretical understanding of decentralized and loosely structured organizational forms, allowing for a more complete conceptual framework in which contemporary social movements can be explored. In addition to organizational structure, an exploration of public space and its use is necessary to include in the discussion of FNB as within Portland the use of public space is essential to organization's operation.

Literature pertaining to both socially constructed and physical space is relevant here as Portland FNB not only creates space with meaning, but also relies on being able to physically access space in order to engage in direct action. Portland FNB embeds social relations within the material world, thus creating alternative economic models that resist capitalist market-based methods of exchange. The interstitial nature of contemporary social movements reflects a precarious existence of these groups and organizations and is in need of scholarly attention. Operating within a space that one is simultaneously attempting to radically alter is not a common case of existence. Furthermore, Portland FNB operates within the city and often calls attention to injustices that are commonly associated with an urban environment (poverty, homelessness, gentrification, etc.).

As such, this case study offers a more complete picture of the organizational structure that is frequently associated with the characterization of "new" social movements and the contested status of public space especially when reclaimed for collective use. As decentralized, non-hierarchical, organizations claim urban space in furtherance of democratic ideals, the contradictory status of public space can be more 
clearly parsed out. As cities are subject to reorganization due to the implementation of neoliberal policies, Portland FNB highlights how attempts to counter this process are met with resistance. Rather than the state being diametrically opposed to the market, this case study highlights the ability of the state to be flexible and adaptable in maintaining a physical and institutional landscape in support of larger neoliberal ideals. While the organizational structure of "new" social movements may facilitate the ability to engage in democratic ideals and practices, democratizing the urban landscape is riddled with difficulty.

This case study contributes to the bodies of new social movement literature and urban sociology literature by drawing connections between the two. The case study of Portland FNB sheds light on how loosely structured social movement organizations attempt to extend a more democratic, alternative model to the larger public. This extension opposes the loss of democratic participation and social goods commonly associated with neoliberal policies. Portland FNB's proactive reclamation of public space is met with resistance, highlighting the way in which neoliberal policies entrench themselves at the local level and the role of local governing bodies in maintaining a favorable institutional framework. 


\section{CHAPTER III: RESEARCH METHODS AND DESIGN}

This study is guided by three main research questions: 1) What is the organizational structure of Portland FNB?, 2) Do Portland FNB respondents understand the organizational structure to be an alternative organizational model and if so, how?, and 3) How is Portland FNB's use of public space reflective of its organizational dynamics and principles? This study explores the organizational structure of Portland FNB and how the organizational model is reflective of anti-capitalist and anti-authoritarian values and principles which informed the commitment to use public space for meal servings. My goal is to provide a holistic understanding of Portland FNB in order to encourage further research into organizational structure and the use of public space by other SMOs.

\section{Framing the Case}

Portland FNB is part of the large international organization, FNB. FNB spawned out of the anti-nuclear movement with the first “action” or food distribution line being set up during a First National Bank of Boston stockholder's meeting on March $26^{\text {th }}$, 1981. A group of anti-nuclear protesters served and received free soup intending to create a piece of street theater that would harken back to a 1930’s Depression Era soup line (Butler and McHenry 1992). Unexpectedly, individuals from the homeless community entered the line and participated in this "piece of theater". The group continued to serve free meals at subsequent protests, eventually splintering from the larger anti-nuclear movement and continuing to engage in direct action by serving free meals to a primarily homeless population. From its inception, FNB has sought to recognize the existence of poverty as a form of structural violence. The name FNB, is a slogan calling for the state to invest in providing basic necessities for survival instead of spending vast sums on the military, an 
inherently violent endeavor. Currently, it is estimated that nearly 500 chapters exist nationally and another 500 chapters internationally. It is hard to have an exact count because FNB is very dynamic, chapters may "pop-up” in one city, while other chapters in another disband (Spataro 2014).

In line with its anti-authoritarian values, each FNB chapter operates autonomously. Each chapter serves free vegetarian or vegan meals within public space to whomever. Heynen argues that FNB attempts to alter the geography of survival which consists of the "socio-natural conditions and structures which make human survival possible.” (2009:1231). Heynen further argues that FNB has the potential to change the city as it makes poverty and resistance visible by providing free meals in public spaces with the intention of changing the geography of survival as well as how the individuals are contained by a neo-liberal state (2009:1235). Heynen makes it clear that FNB is not a charity as it does not depend on private donations, state funding or a permanent influx of “clients” (2009:1226). This is also indicative of Do-It-Yourself culture, as FNB does not seek donations in the form of capital, but rather builds relationships with local food producers or identifies locations for dumpster diving (Spataro 2014). FNB does not seek permission from the state to engage in the act of serving free meals; rather participants consciously operate absent of formal permission.

For FNB, public space is imperative because the movement operates as a form of visible resistance, by engaging in non-violent civil disobedience. As FNB serves free meals to the public, it also creates a "socially embedded, decommodified circuit". A socially embedded, decommodified circuit is defined as "any form of economic activity (broadly defined) that influences and reorients the motivations, incentives, interests, 
values, priorities, and behavior of economic actors to promote social priorities and egalitarian objectives rather than market rationality" (Vail 2010:329). Surplus food that is destined to be thrown away as it is deemed to longer be of value as a commodity is "repurposed" and the sharing of this food asserts that healthy and nutritious food is a human right (Heynen 2009:1227). Individuals that utilize the meal serving are not expected to engage in a traditional process of exchange; rather meal serving provides an opportunity for activists and marginalized populations to occupy the same space in addition to sharing the same meal. Activists eat in close quarters with those they intend to serve, creating an opportunity for community building.

Portland FNB provides a unique opportunity to examine a decentralized, nonhierarchical SMO that routinely occupies public space, in accordance with guiding values and principles. Within Portland one of the two FNB groups has its origins in Occupy Portland. This has impacted several participants' worldview and values. The values that guide Portland FNB, influence the structure of the organization, in turn impacting the strategy Portland FNB utilizes in resisting urban inequality. Both the structure and the way Portland FNB operates are significantly different than that of the state or other nonprofit organizations, thus Portland FNB presents itself as a viable case for further exploration.

\section{Approach Used}

In order to examine and further understand these various components, this study utilizes a qualitative approach that focuses on participant's individual perceptions, understandings, and experiences. Data collection methods included semi-structured interviews, participant observation, and limited analysis of the FNB website and specific 
chapter's Facebook pages. The use of multiple data collection strategies increases credibility as the data can be cross-referenced based on strategy and point of view (Baxter and Jack 2008:556). Interviews were conducted with individuals that were "heavily involved" with Portland FNB. For this study, "heavy involvement” is meant to be synonymous with regularly attending the weekly meal serving (nearly every week without fail) and taking an active role in ensuring the serving is completed. Those heavily involved constitute what those involved with FNB refer to as "bottom-liners"; individuals who take on a large share of responsibility in completing the meal serving. These individuals were identified through my own observations at the meal servings or were verbally identified as "bottom-liners" by other interviewees. These individuals assume added responsibility and accountability and therefore are identified as having intimate and essential knowledge of Portland FNB.

\section{Data Collection}

\section{In-depth Interviews}

Over the summer and fall of 2014, I conducted ten semi-structured, anonymous interviews. Initial participants were recruited through informal conversations held at weekly meal servings and friends of faculty. From my observations, participants that took an active role in preparing the meal on a regular basis were identified as being integral potential interviewees. Additional participants were then identified through the use of snowball sampling. Eight of the ten interviewees were heavily involved at the time of the interview. The two remaining interviewees had recently ended their involvement with Portland FNB. Three of the ten interviewees were primarily involved in the Downtown cell, while seven of the ten were primarily involved with the Inner SE cell. The time 
spent in the field was immensely valuable as it enabled the identification of individuals that were integral to SMO, as well as, provided ample opportunities to build rapport. The small number of interviewees illustrates the limited number of those heavily involved in Portland FNB. Interviewees often identified one another as being vital to the SMO's operation. Although the sample size is small, it is representative of Portland FNB volunteers and active participants.

Before inviting individuals to participate in a semi-structured interview, I spent several weeks in the field. From the initial stages of the research, I made it clear that I wished to participate in and observe the meal servings, with the intention of conducting future interviews with those heavily involved in the SMO. The interview was framed as a way to explore and examine alternative organizational models of SMOs that actively resist neoliberal and capitalist logic. As the Portland FNB community is small and tightknit, fully disclosing my role as a researcher and actively building rapport was essential to recruiting interviewees. As the interviews were semi-structured, follow-up questions were often specific to the interviewee. Despite this potential variation in the order of the interview, all interviews included the same discussion topics:

- How interviewees came to be involved with Portland FNB

- How do interviewees understand their level of involvement with Portland FNB

- What interviewees understand to the be the goals of Portland FNB

- What is the structure of Portland FNB

- What are the benefits and drawbacks of this particular structure

- How are resources such as food stuffs, cooking utensils, etc. obtained

- What are the difficulties associated with engaging in direct action

- In the future, what would Portland FNB ideally accomplish

Interviews also gathered information pertaining to the demographic characteristics of each interviewee. Table 1 below provides an overview of the demographic 
characteristics of all interviewees and includes the pseudonyms given to the interviewees. As indicated by the table, the sample is overwhelmingly white and disproportionately educated when compared to demographic characteristics of the city as a whole.

According to the U.S. Census Bureau, in 2013, approximately 76\% of Portland residents were white and 44\% of residents had a Bachelor's degree or higher (2009-2013).

Although, the individuals eating meals at the Portland FNB servings are not the focus of this study, they take on a major role in whether a serving is considered "successful" or not. At the downtown serving, the majority of individuals eating meals are homeless. I cannot speak in terms of statistical significance, but the population utilizing the meal serving is more racially and ethnically diverse than the FNB participants. Rarely individuals boarding and deboarding the train will grab something to eat or make casual conversation with the FNB participants. The Inner SE cell is more diverse in terms of "groups". From my observation, at any given meal serving there may be nuclear families, homeless individuals, transients, etc. intermingling near the pavilion.

Table 1. Portland FNB Questionnaire Data

\begin{tabular}{|l|l|l|l|l|l|}
\hline Pseudonym & Race & Gender & $\begin{array}{l}\text { Highest } \\
\text { Level of } \\
\text { Education }\end{array}$ & $\begin{array}{l}\text { Primary FNB } \\
\text { Cell Involved } \\
\text { With }\end{array}$ & $\begin{array}{l}\text { Length of } \\
\text { Involvement }\end{array}$ \\
\hline Janis & 2 or more & Female & $\begin{array}{l}\text { Some } \\
\text { College }\end{array}$ & Downtown & 1 year \\
\hline John & White & Male & Bachelor's & Downtown & 3 years \\
\hline Pete & White & Male & Bachelor's & Downtown & 2 years \\
\hline Robert & White & Male & Bachelor's & Inner SE & 1.5 years \\
\hline Paul & White & Male & Graduate & Inner SE & $\begin{array}{l}\text { On/off for 15 } \\
\text { years }\end{array}$ \\
\hline Carol & White & Female & Bachelor's & Inner SE & 2 years \\
\hline Kurt & White & Male & Bachelor's & Inner SE & 2.5 years* \\
\hline Hollie & White & Female & Bachelor's & Inner SE & 1 year* \\
\hline Lauryn & White & Female & $\begin{array}{l}\text { Some } \\
\text { College }\end{array}$ & Inner SE & $\begin{array}{l}6 \text { months (20 } \\
\text { years overall) }\end{array}$ \\
\hline
\end{tabular}




\begin{tabular}{|l|l|l|l|l|l|}
\hline Aretha & White & Female & $\begin{array}{l}\text { Some } \\
\text { College }\end{array}$ & Inner SE & 1 year \\
\hline
\end{tabular}

*Indicates individuals are no longer regularly involved

Participant Observation

Over the course of this study, approximately 50 hours of participant observation was conducted at two different sites within Portland. I actively participated in meal preparation, the servings, and other organizational functions. As Table 1. indicates, Portland FNB consists of two autonomous FNB chapters. Each chapter conducts its own weekly meal serving. By observing the operation of Portland FNB, I was able to answer the research questions posed in greater depth. Participant observation provided insight into the inner-functioning of each cell as I subjectively observed individuals’ behavior. Observations were recorded in the form of fieldnotes. Sites for observation included the meal preparation and serving sites in downtown and inner SE Portland and a private residence (Janis’ primary residence). During my time in the field the private residence served as preparation site for the Pacific Northwest Social Forum. Both cells of Portland FNB collaborated in creating a day's menu for the social justice oriented event.

Meal preparation occurs at two sites; at a local non-profit located in downtown Portland (Downtown cell) and a private residence on the east side (Inner SE cell). The meal servings occur in public spaces, more specifically, a public transit station and a public park. These are meant to be highly visible, inclusive events, with all persons being invited to participate. For me, observations of the meal preparation process provided insight as to how tasks are divided within the organization, while the meal serving itself illustrated how Portland FNB utilizes public space. These observations also provided an 
overview of how each chapter of Portland FNB operates on a day-to-day basis. The entire process typically takes five hours, allowing for ample data collection.

\section{Justification}

In order to fully explore and examine Portland FNB, a case study approach is best utilized. Baxter and Jack (2008) argue, according to Yin (2003), that a case study design is particularly useful if the contextual conditions cannot be separated from the phenomenon being studied (545). Individuals’ actions are inextricably linked to the meanings that are assigned to those actions by the actors themselves, thus "face-to-face interaction and observation in the natural setting” are necessary in order to understand individuals’ deeper perspectives (Marshall and Rossman 2010:91). In addition, the utilization of a combination of data collection strategies is necessary for doing a successful case study. Taking a case study approach allows for the collection of data from various sources, while also taking into account the context in which a specific phenomenon occurs (Baxter and Jack 2008). Both participant observation and face-toface interaction through semi-structured interviews allow for exploration and examination of understandings that may otherwise not be possible within the context of Portland FNB. Marshall and Rossman (2010) and Baxter and Jack (2008), seem to indicate that the use of multiple data collection strategies, in addition to immersing one's self in the setting, is necessary in order to gain deep levels of understanding. Thus, in

order to thoroughly capture the complex social world in which individuals involved with Portland FNB are situated, multiple qualitative data collection strategies are necessary. 


\section{Data Analysis}

From the beginning I analyzed all the collected data (content produced by Portland FNB and other chapters, field notes from observations, and interview transcripts) through an open coding process. Coding refers to giving the data segment a short name that not only summarizes, but categorizes the data as well (Charmaz 2006:43). As the coding process was open, a pre-established codebook based upon a structured interview guide was not used. This allowed for more open and honest interviews, where participants could help determine the course of the conversation. The codes include both broad categories ("parent” codes) and more specific ones (“child” codes), with “child” codes. "Child” codes further subdivided the broader "parent” codes into more specific groupings. Preliminary codes heavily relied on themes consistently present in previous literature. These preliminary codes consisted of very general and broad categories such as non-hierarchical, direct democracy, direct action, etc.

Throughout the course of coding, codes were combined, eliminated, collapsed, etc. Through the use of analytic memo-writing, I was able to reflect upon the codes I created and thus analyze my data from the beginning of the coding process (Charmaz 2006). Concepts from previous literature guided my initial coding process. A general framework was built around themes pertaining to organizational structure, democratic practices, and direct action as they emerged during the process. Interviews were coded more than once, in order to fully identify common themes.

\section{Advantages and Limitations}

The primary advantage of a case study design is the reliance upon multiple elements of data collection by design. The combination of these elements allows for the research 
questions to be addressed from different perspectives. Although this research is not generalizable in the quantitative sense; the findings of the study are somewhat transferable as FNB is an international social movement with chapters in various cities throughout the world. The sample included in this study is not randomly selected but it does represent in depth, the many dimensions of Portland FNB. The level of transferability may vary, but as various FNB chapters have a stated affinity for operating non-hierarchically, utilizing direct democratic practices some degree of transferability is likely. However, this study is not generalizable. The small sample size inhibits the ability to make broad claims and it is possible the Portland chapter of FNB may operate drastically different than the typical FNB chapter. Despite the mentioned limitations, Portland FNB provides a theoretically interesting case that elucidates how values, structure, and strategy influence one another, while also highlighting the difficulty associated with occupying public space.

\section{Role of Researcher}

From the initial stages of this research project, I disclosed my identity as a researcher to "heavily involved". Individuals utilizing the meal serving or those participating sporadically were not explicitly informed of my study. In reference to those heavily involved, the disclosure of my identity could have possibly have impacted their natural behavior. However it was important to me to be transparent throughout the entire research process. By regularly attending the meal servings, my presence became a "fixture" of the organization. This is not to say my role as a researcher was forgotten or ignored but rather by spending a prolonged amount of time in the field, my presence became less apparent. Field notes were only taken when there was time "exit the field" momentarily. In addition, the interviewees and I had several demographic characteristics 
in common. Being a young, white male, graduate student allowed me to more easily become involved with the organization.

All interview participants remained confidential. As all interviews were conducted in person, each interviewee was given an informed consent form to read over and sign. I also offered each interviewee a transcript of our interview to further increase transparency. In summary, I attempted to disclose my identity as researcher to all interviewees from the initial stages of my research. I made further attempts to be transparent, in order to build more trusting and honest relationships during the tenure of the project.

\section{Conclusion}

This case study consists primarily of in-depth interviews and participant observation. In-depth interviews provided insight into participant’s unique understandings of their involvement in Portland FNB and the organizational structure of the SMO. Participant observation provided a glimpse into the day-to-day operation of either chapter of Portland FNB, as well as participant's behaviors. Finally, analysis of other organizational material helped to illustrate the values and larger principles FNB has an affinity towards. In qualitative research such as this, the major limitations include researcher subjectivity and generalizability. Despite these shortcomings, the use of multiple data collection strategies helps to increase the credibility of this study.

Ultimately, I decided what was to be included and excluded but having a concern for accurately capturing the respondents' understandings and Portland FNB's mission, I feel the participants and Portland FNB are represented justly. 


\section{CHAPTER IV: THE VALUES AND STRUCTURE OF PORTLAND FNB}

\section{Overview}

This chapter will address my first two research questions: 1) What is the organizational structure of the movement of Portland FNB? and 2) Do Portland FNB respondents understand the organizational structure to be an alternative organizational model and if so, how? In the following pages, I will first discuss the origins of FNB, how FNB operates within Portland specifically, and then how those involved with Portland FNB do understand it as being an alternative organizational model with implications for operating outside the state. I argue that Portland FNB seeks radical structural change rather than reformation by disregarding and questioning the effectiveness of the state and other formal institutions.

Portland FNB operates as an alternative organizational model, vehemently rejecting centralized power and more bureaucratic forms of organizing. Values such as inclusiveness, accessibility, and self-empowerment have continued to influence how the movement organizes and operates. Within Portland, these values are not only observable during movement functions or events, but are also elaborated upon during open-ended interviews with Portland FNB participants.

The organizational practices and dynamics of Portland FNB are illustrative of the larger principles that would constitute a more just and equal society. Through organizational practices, Portland FNB embodies and potentially actualizes these values and practices. The structure of Portland FNB itself is a symbolic message, rejecting authority and top-down organizational structure. Specifically, I will show that, in working 
towards social justice, Portland FNB creates a space where leadership exists without formal positions of power and knowledge is dispersed throughout the social movement organization by those most heavily active in sustaining the movement. Finally, I contend that Portland FNB builds community between various communities within an urban environment.

\section{Food Not Bombs as a Social Movement Organization}

Taking into account how FNB came into existence, it is possible to conceptualize it as both a social movement and a social movement organization. Participants within FNB, collectively act upon values and beliefs counter to the dominant culture, (Buechler 2000:36) while also socially constructing an organization that can support various movements simultaneously. A SMO can be defined as "a complex, or formal, organization which identifies its goals with the preferences of a social movement or a countermovement and attempts to implement those goals” (McCarthy and Zald 1977). In comparison to more formal, bureaucratic SMOs, FNB is vastly different in terms of organizational structure and dynamics. Both resource mobilization theory (McCarthy and Zald 1977) and political opportunity theory (McAdam 1982) are inadequate in exploring and understanding FNB as they focus on more formal SMOs and factors affecting their “success”. Therefore, NSM theory is "best” utilized to characterize and understand FNB. Table 2. located below outlines the characteristics of FNB in comparison to other more moderate, leftist SMOs.

Table 2. Basic Characteristics of Mainstream and Oppositional SMOs

\begin{tabular}{|l|l|l|}
\hline Basic Characteristics & Mainstream & Food Not Bombs \\
\hline
\end{tabular}




\begin{tabular}{|c|c|c|}
\hline Structure & Centralized “Authority” & Decentralized “Authority” \\
\hline Ideology & "Embraces” Authority & Opposes Authority \\
\hline Type of Leadership & Formal Leadership & No Formal Leadership \\
\hline Movement Focus or & Reform Oriented & Radical Change \\
Goals & & \\
\hline
\end{tabular}

FNB practices consensus based decision-making, avoids centralized authority and has no formal leadership. The adoption of these organizational practices reflect broader organizational principles such as democracy, decentralization, anti-authoritarianism, and the rejection of hierarchy. These values often result in the favoring of a more loosely structured organizational form which has been argued to be characteristic of NSMOs (Melucci 1980; Buechler 2000). Furthermore, the rejection of formal authority illustrates the inclusion of anarchist organizational principles and an overall preference for political and social equality (Juris 2009). A scan of publicly available documents such as various FNB chapter’s Facebook pages and websites illustrate the broader principles FNB values within the context of the organization. The following excerpt from the Seattle chapter's website demonstrates an affinity for anarchy as it reads:

"But then again, we don't need the United Nations (or the church, or president, or party chairman) to tell us that food is a right. It's just common sense. They can pass resolutions into perpetuity, but that in and of itself has no (effect) on improving the living conditions of billions across the globe. In fact, no government sanctioned or sponsored initiative will ever be enough. Thankfully, we aren't waiting for their okay anyway!”

This excerpt most importantly illustrates the rejection of formal authority in the form of supranational institutions and the state. It is clearly apparent that the Seattle 
chapter of FNB seeks to work outside the state without its formal approval or collaboration as the state and other institutions are deemed unable to improve the quality of life. This excerpt also touches upon the belief that food is right and not a commodity. This belief is also held by the Boston chapter of FNB as their website reads:

"The main ideology of Food Not Bombs is that food is a right, not a privilege. Food Not Bombs provides free vegan meals to the public, regardless of whether one is hungry or food secure. We recognize that there is so much food wasted in this country, and yet people are still starving. We see this as violence." In various instances, hunger and violence were considered to be analogous by several national FNB chapters. These FNB chapters have placed themselves squarely within the larger food justice movement. Just Food (2010) defines food justice as “communities exercising their right to grow, sell, eat [food that is] fresh, nutritious, affordable, culturally appropriate and grown locally by with care for the well-being of the land, workers and animals” (Alkon and Agyeman 2011). The concepts of food access and food sovereignty must also be included in any discussion of food justice. Food access refers to "the ability to produce and consume healthy food" while according to Via Campesina, (2002) food sovereignty refers to a "community's right to define their own food and agricultural systems” (Alkon and Agyeman 2011). The excerpts from the FNB chapters above, indicate these chapters have taken a more radical stance by addressing food sovereignty rather than food security as the SMO defines the act of consuming food as occurring outside the framework of the market and provisioning from the state.

These excerpts also hint at issues of privilege within the food justice movement. The food justice movement is often dominated by white, middle-class narratives, further marginalizing impoverished communities and those of color (Alkon and Agyeman 2011). The adherence to serving "vegan" meals can result in an alternative food system in which 
class and racial privilege can go unaddressed. However, within the same excerpt these FNB chapters make it clear that food is seen as a human right. These chapters move beyond a food access to address food sovereignty. Mares and Peña (2011) argue that within the context of food security, food is viewed as a "nutritional commodity" while food sovereignty situates food as a “fundamental human right” (203-204). In addition to framing food as a right, both The Nation of Islam and The Black Panther Party saw food serving as a way to build community and develop self-determination. In both cases specific, though divergent cuisines, were used to form race-based identities; organic fruits and vegetables in the case of the NOI and "soul-food" in the case of the BPP (McCutcheon 2011; Alkon 2012). Through the principles and practices adopted by various FNB chapters, political identities revolving around food are formed as the first excerpt indicates.

Currently, it is estimated that there are approximately 500 FNB chapters in the United States and an additional 500 chapters located throughout the globe. Although FNB has grown considerably since the early 1980's it has met local resistance. The first major conflict occurred in San Francisco. In 1988, on Labor Day, 54 participants were arrested. This catapulted FNB into the national and international spotlight, (Butler and McHenry 1992) but also drew critiques of the way urban space is regulated. Currently, the regulation of public space is directly affecting the Ft. Lauderdale chapter of FNB. The chapter is suing the city, declaring a city ordinance unconstitutional, as it has essentially made it impossible to legally serve food in public. Harvey argues that the struggle over urban space is currently characterized by the zealous protection of private property, uneven geographical development and the displacement of peoples as land is seized 
sometimes violently for “development”(2012:9-11). Similarly, Mitchell and Heynen (2013) argue that public space and individuals are increasingly subject to regulation and surveillance. For example, dumpsters are often monitored by CCTV cameras in order to deter individuals from “diving” for food and other items (618). This of course implicitly targets the homeless population and regulates survival.

The ordinance enforces spatial stipulations (sites must be spread out, etc.) and “sanitary" regulations (requiring distributors to provide portable toilets, etc.), making make it extremely difficult for FNB to carry out their meal servings (Barszewski 2015). The National Coalition for the Homeless reports that since January 2013, 21 U.S. cities have passed legislation restricting the sharing of food with the homeless in public (National Coalition for the Homeless 2014). Fortunately, in Portland, municipal ordinances do not exist that restrict the sharing of food in public and thus FNB can operate within the city without significant resistance. This broader food justice framework provides a springboard for further analysis of Portland FNB.

\section{“The SWAT Team of Radical Cooking”: Portland Food Not Bombs}

The principles of Portland FNB are similar to those of the chapters previously mentioned as their mission statement, on their Facebook page reads:

"By sharing this food, most of which would otherwise be dumped into a landfill, or composted at best, we are able to provide delicious, nutritious, free vegan \& vegetarian food to our children, friends, and neighbors, without regard to their means or 'status'; to feed all levels of the community..."

Portland FNB has two autonomous chapters. Each chapter conducts one weekly meal serving in separate locations located within Portland (Downtown and Inner SE). The Downtown meal serving is in close vicinity to existing homeless shelters, missions, 
and other soup kitchens. The preparation space is "loaned” by Right To Dream Too (R2D2), a non-profit focused on providing safe sleeping space for the homeless. R2D2 is located a few blocks away from the serving site, in an empty lot in downtown Portland. The Downtown serving occurs every Tuesday and begins at 6:30 p.m. sharp. The vast majority of those who utilize this serving are homeless individuals. Although the serving is near a busy public transit station, individuals outside of the FNB network rarely partake in the meal. Pete, an interview participant, expressed frustration at this and stated that servings draw from the same populations week after week; "activists, radicals and street kids”.

The Downtown cell of Portland FNB has its origins in experiences of serving meals at Occupy Portland. John and Janis originally became involved with FNB through their participation in Occupy Portland, as being part of the Food and Garden Team was an important experience in terms of working towards food justice. The demise of Occupy Portland stimulated a desire for continued action, resulting in the formation of the Downtown cell. Pete resides in a community house owned by Janis, engaging in community action in exchange for lower rent. The serving typically comes to an end when the flow of people dwindles to a handful of people (around 8:00 p.m. to 8:30 p.m.).

The atmosphere surrounding the Inner SE serving is vastly different as the serving occurs at a public park and coincides with "Monday Funday", an informal gathering which happens every week. In terms of class, the Inner SE serving is more diverse as middle-class individuals, the homeless, transients, etc. all utilize the serving. However, the vast majority of individuals taking part in this meal are individuals from the extended social network of those heavily active within the cell (other activists, friends, etc.). This 
serving also begins at 6:30 p.m. and typically ends at 8:30 p.m. with the length of cleanup depending on the number of volunteers participating. Those involved in the Inner SE cell, came into contact with FNB through social networks and noted that FNB was described to them as a place to get "free food". Table 3. located below, provides a demographic description of the interviewees to further contextualize the discussion of the findings.

Table 3. Portland FNB Questionnaire Data

\begin{tabular}{|c|c|c|c|c|c|}
\hline Pseudonym & Race & Gender & $\begin{array}{c}\text { Highest } \\
\text { Level of } \\
\text { Education }\end{array}$ & $\begin{array}{c}\text { Primary FNB } \\
\text { Cell Involved } \\
\text { With }\end{array}$ & $\begin{array}{c}\text { Length of } \\
\text { Involvement }\end{array}$ \\
\hline Janis & $\begin{array}{c}2 \text { or } \\
\text { more }\end{array}$ & Female & $\begin{array}{c}\text { Some } \\
\text { College }\end{array}$ & Downtown & 1 year \\
\hline John & White & Male & Bachelor's & Downtown & 3 years \\
\hline Pete & White & Male & Bachelor's & Downtown & 2 years \\
\hline Robert & White & Male & Bachelor's & Inner SE & 1.5 years \\
\hline Paul & White & Male & Graduate & Inner SE & $\begin{array}{c}\text { On/off for 15 } \\
\text { years }\end{array}$ \\
\hline Carol & White & Female & Bachelor's & Inner SE & 2 years \\
\hline Kurt & White & Male & Bachelor's & Inner SE & 2.5 years* \\
\hline Hollie & White & Female & Bachelor's & Inner SE & 1 year* \\
\hline Lauryn & White & Female & $\begin{array}{c}\text { Some } \\
\text { College }\end{array}$ & Inner SE & $\begin{array}{c}6 \text { months }(20 \\
\text { years overall) }\end{array}$ \\
\hline Aretha & White & Female & $\begin{array}{c}\text { Some } \\
\text { College }\end{array}$ & Inner SE & 1 year \\
\hline
\end{tabular}

*Indicates individuals are no longer regularly involved

Interviewees were spilt evenly in respect to gender. Overwhelmingly, the interviewees identified as being "white" in terms of their racial/ethnic identity. Only one participant identified as being more than one race/ethnicity as she noted her father is Central American. As a group, they were also highly educated with each interviewee having at least some post-secondary education. At the time of the interview, Kurt and Hollie were not regularly involved in with Portland FNB. The specific ages of the 
interviewees were not included in the table. The age of the interviewees ranged from 26 to 44 years in age. Demographically speaking, I cannot say that my sample is statistically representative of the movement as a whole but these individuals do represent the core group of Portland FNB. Both cells only serve vegan meals, despite several individuals within either cell not being vegan themselves. The significance of serving vegan meals is summarized by Janis, an interviewee who is heavily active in the downtown chapter, as "Most of what we serve is vegan but we have very few vegans that cook. I think for most of us it's about not supporting the industrial meat model and the factory farming model..." Janis later goes on to say that the industrial meat system is "ecologically and ethically horrible" for both workers and livestock and thus not serving animal products coincides with practicing non-violence and supporting more local agriculture. Strictly adhering to veganism serves to maintain Portland FNB principles rather than being a formulated identity of those interviewed.

\section{Working Together}

The Portland FNB chapters operate autonomously but collaboration occurs. Collaborations range from attending the other chapter's meal serving on a casual basis, to actively participating in the preparation process. However, during cross-chapter participation, individuals rarely undertake the most important tasks such as the preparing the staple dishes. One chapter is not the "parent" of the other and each chapter strives to maintain autonomy and operate independently.

At times the chapters will come together collectively to provide support in the form of meals for larger activist events (marches, forums, etc.). For example, during my time in the field, Portland FNB prepared meals for the Pacific Northwest Peoples 
Movement Assembly held within Portland. John also described in the past Portland FNB has provided meal support for the May Day March and Pitch-A-Tent, the one day where camping is legal in Portland. Engaging in these instances of planned direct action requires both chapters to collaborate due to the amount of meals Portland FNB seeks to provide. This also creates a situation in which Portland FNB is operating as a "single" entity. Therefore, these events are carefully selected based on the action being representative of "the same non-aggressive beliefs..." various other chapters including those in Portland have identified as being a core principle of the SMO.

From observations made in the field and through interview data, participation within FNB is very fluid with individuals decreasing or increasing their participation without repercussions. Oftentimes during interviews, participants gave names that I did not recognize. Upon inquiry I would learn they had ceased to be heavily involved. The participation of these individuals were often integral to Portland FNB as they were responsible for obtaining preparation space, creating the Facebook page, etc. Hollie best summarizes the dynamism of the movement by stating:

"It is incredibly organic and transitive and changing. Like I said before the people that have come through FNB... it kind of comes in generational waves. Not generational waves but cohort waves..."

Because of the ever-changing composition of FNB, participants must be particularly adaptable in order to sustain Portland FNB. In terms of the tasks they assume responsibility for, the loss of participation from important and integral individuals cannot be the potential dissolution of the chapter. Due to this, leadership takes a vastly different form within Portland FNB in comparison to a top-down structural model. 
In both chapters the core tasks for sustaining the organization are the same, though there are some chapter specific tasks such as the provision of preparation space by Paul in the Inner SE cell but this is the exception. Table 4. below outlines the necessary tasks for sustaining either chapter.

Table 4. The Core Tasks of FNB

\begin{tabular}{|c|c|}
\hline Essential Task & Description of Task \\
\hline "Pick-ups" & $\begin{array}{c}\text { Picking up produce from organic distributor and vendors at } \\
\text { farmers markets }\end{array}$ \\
\hline Meal Prep & $\begin{array}{c}\text { Chopping produce for cooking or eating raw } \\
\text { preparing the an entree }\end{array}$ \\
\hline $\begin{array}{c}\text { Prepping the Main } \\
\text { Dish }\end{array}$ & $\begin{array}{c}\text { Entails spicing the rice and lentils, deciding upon and } \\
\text { vice versa once the serving is over }\end{array}$ \\
\hline $\begin{array}{c}\text { Transport } \\
\text { Dishing hot meals for individuals }\end{array}$ \\
\hline Serving & $\begin{array}{c}\text { Bringing the meal from the prep site to the serving sing } \\
\text { down tables }\end{array}$ \\
\hline Clean-up & Washing, drying and putting away pots and pans, wiping \\
\hline
\end{tabular}

At times, the irregular task of purchasing essential items such as propane and staple items such as rice and lentils must be done specifically within the Downtown cell. John or Janis typically complete this task when needed. Janis assumes additional responsibility for providing beverages such as tea, coffee, lemonade, etc. on a weekly basis. Paul provides his apartment as a preparation site for the Inner SE cell, which is integral to maintaining the organization as it currently is. However, this is not a core task that FNB participants are expected to undertake. The most important task for apparent reasons is completing the "pick-up”, yet this requires the most equipment (bike and trailer). This results in it being the least accessible task to those not heavily involved in 
Portland FNB. Although every interviewee from the Downtown Cell engages in this activity, John is primarily responsible for completing the organic distributor "pick-up”. In the Inner SE cell Robert and Aretha take the lead on ensuring "pick-ups” are done. Within Portland FNB, these individuals are considered "bottom-liners". Aretha describes "bottom-lining” as:

"To bottom line a meal is to make sure that you are present and able to help any new volunteers finding equipment and understanding how to use the equipment and making sure that there is what we consider a full meal which is three dishes often including a grain for the meal. It also means that making sure that there are enough servers at the park and volunteers to clean up at the end of the serving."

"Bottom-liners" are responsible for sustaining the organization and ensuring that a "full meal” is possible. Tasks such as meal preparation and clean-up are completed by various individuals, including those heavily involved in FNB or those loosely connected to the SMO (new participants, etc.).

\section{A Portrait of a Meal Serving}

The following excerpt from my fieldnotes illustrates a typical serving, from the meal preparation to the start of the actual serving. The excerpt gives a "glimpse" into the day to day operations of the Downtown cell. Individuals' behaviors and the type of conversations they engage in, often represent larger organizational values and principles. It also provides an opportunity for participants to construct and agree upon the values and principles of FNB as an SMO.

"A typical day at the Downtown cell's serving consists of the following. Upon my arrival (approximately 3:30 p.m.), John is already at Right To Dream Too. He is often wiping down the table that is used for meal preparation or getting ready to prepare the rice and lentils (starting the propane burner, filling a pot with water). Pete arrives approximately 15-20 min "late" as he was picking up bagels from a bakery on the East Side. Arriving "late" to the meal preparation is not frowned upon and participants do not sanction one another. As Pete explained one doesn't 
need to worry about being "fired from FNB". Once the water is brought to a boil, John adds the rice and lentils in together without measuring them. All the participants engage in chopping a vast array of vegetables and fruit. A donation of individually packaged chips are brought by individuals who leave immediately after dropping them off. Jokes are made about the amount of preservatives that must be in the chips and it is decided they cannot be served. John watches over the rice and lentils very carefully and when they are deemed done he begins to spice them. Taste-tests are taken and the rice and lentils are "approved" by the group. Pete and Janis begin loading their bikes with the food. The bikes, which are locked up near the entrance of R2D2, are splattered with various stickers referencing political ideologies, acknowledging local food producers, etc. As we arrive near the public transit station under the Burnside Bridge, approximately five or so homeless individuals are waiting. John hangs the "Food Not Bombs" banner, which depicts a clenched fist holding a purple carrot, across two poles. The food and social justice literature pertaining to the Homeless Bill of Rights, oil pipelines, etc. is scattered throughout the line. John yells, "Food Not Bombs!" to begin the meal.”

More than food is being made however. Each meal serving is an opportunity for those involved with the Downtown cell and Portland FNB at large to practice and embrace the values of FNB as an SMO. For example, from the excerpt, gaining the groups "approval” of the rice and lentils embodies the preference for a more egalitarian and democratic organizational model. It also provides an opportunity to engage in consensus decision-making. Although, this decision may seem minute, it serves a learning experience for all those involved. As the organizational model of FNB is radically different from a typical top-down structure, socialization is necessary in order to operate in conjunction with the larger values and principles of FNB as an SMO.

\section{Assuming the "Lead": Leadership within Portland FNB}

In terms of tasks, individuals who heavily participate in the movement or bottomliners, do assume a role that requires added responsibility and accountability. Despite Portland FNB's explicitness in operating as a non-hierarchical social movement organization, operating without a formal hierarchy is not synonymous with an absence of 
leadership. Nearly all of the participants that self-identified as bottom-lining meals acknowledged that they do fulfill a leadership role within the movement. Leaders often have prior experience in professional kitchens or extended experience with Portland FNB. These individuals do not hold office or formal positions. Rather, these leaders are “task-oriented” focused on completing the weekly meal serving, the movement's primary goal (Aminzade et al. 2001). As FNB explicitly states a preference for horizontality, it must be examined if this form of leadership is understood as being synonymous with formal authority and a disguised top-down power structure. Task-oriented leaders within Portland FNB are also "self-effacing" as they are able to separate themselves from their "power" in order to increase the likelihood that the movement will continue to sustain itself (Aminzade et al. 2001). Within FNB, those who bottom-line meals, understood that the time spent within the movement and the knowledge that is accrued during this time, results in an imbalanced relationship between those who are bottom-liners and individuals new to the movement. Pete captures this very succinctly by stating:

“People who've been around a long time obviously know the ins and outs... will kind of be like...sort of more of a leadership role but it's not when we show up to cook it's hey I'm in charge because I hold the position. I can decide what we're cooking. I can decide all this other stuff. It's still pretty open.”

This imbalanced relationship does not go unacknowledged and rather is addressed by those fulfilling a leadership role. Knowledge pertaining to the movement's practices is actively dispersed outwards, rather than being guarded or held onto. Robert explained that these leadership roles are initially necessary for the primary purpose of imparting knowledge necessary for the movement's operation to new individuals. He compared this to a "short training period" that results in individuals being able to operate without 
direction or oversight from a more experienced participant. Both new and experienced participants alike, can step-up to creatively solve various problems that may threaten the ability of the movement to continue operating. John describes the epitome of how leadership should exist within FNB as:

"Everybody has to be their own leader. That's a difficult thing in for people in this society to do. We've been really taught I think to follow leaders and to not lead ourselves. We haven't...leadership qualities I think are not naturally bred in people by this culture or by a lot of households from birth..."

In a sense, FNB provides a space in which leadership can be cultivated and practiced by all individuals without being coerced or forced to be proactive. Near the end of my time in the field, Paul reported to the other FNB participants that he was feeling "burnt-out”, meaning he felt the meal preparation and serving was intruding on his personal life and space. Rather than having to completely halt the meal serving, Lauryn took the lead on collecting donations at the park for an awning in order to move the meal preparation outside. In this instance, one may be more motivated to act due to the magnitude of the issue but nonetheless it serves as an exemplar of how leadership should manifest itself within FNB. Ideally, all participants within FNB would proactively engage in problem-solving and take the lead on various tasks when it is required for the continued function of the movement.

Nearly all the interviewees understood leadership as being a role that anyone could step into when they so desired or circumstances necessitated it. As John indicates, this is antithetical with traditional power relationships. However, valuing nonhierarchical relations and open leadership does not necessitate that individuals will feel comfortable operating within an alternative organizational model. FNB participants do 
not only express an affinity for horizontality, but through various practices the movement institutionalizes this value. Through practices such as consensus decision-making, individuals become acquainted and familiar with an organizational model in which one cannot immediately rely on formalized leadership and thus be their own leader. The organizational model of FNB creates a situation in which individuals must act without being forced and coerced. In order to remain egalitarian, leadership cannot become centralized and therefore everyone must have equal access to leadership roles. It also provides an opportunity to individuals to practice fulfilling a task-oriented leadership where power over others is vehemently resisted. This helps ensure that leadership will continue to exist although in a more democratic form.

\section{A Different Type of Politics}

Decision-making within Portland FNB is consensus-based. Meetings involving both chapters are conducted on a fairly regular basis (every two to three months). Paul describes these meetings as an instance where:

“We all get together and we just talk about...mostly it’s just practical stuff. Who's doing this pickup? Who's going to do that? Should we start thinking about moving forward with this idea or not? Or is somebody stepping on somebody's toes? Something like that. Then sometimes there is ideological things that we talk about like veganism or like safe spaces. That general kind of thing is talked about."

From Paul's description, the meetings primarily focus on the logistics of completing food pick-ups. The coordination of these activities is important, as the two chapters of FNB in Portland often share resources such as food stuffs with one another. Embedded within these meetings, although not immediately apparent, is the importance of transparency within the movement. These meetings function to ensure that information 
is distributed evenly and equally amongst all participants. Several participants understood that making decisions without consulting others firsthand could create rifts within the movement. Those who made decisions without consulting others first were perceived as acting like "managers" or depending on the circumstances possibly misrepresenting the principles of FNB as a SMO. For example, Carol retells a scenario when white hamburger buns, left over from Portland Vegfest were gleaned and then served as part of the meal. These "super-processed" white bread buns are not a staple at FNB servings and this visibly upset other participants particularly because they were not included in the decision to serve an item deemed incompatible with principles relating to food justice, embraced by FNB. At its worst, a lack of transparency was perceived to coincide with a centralized power structure, violating principles such as decentralization and antiauthoritarianism. Janis and John are especially wary of this due to their past experiences with Occupy Portland. In reference to a lack in transparency and other movements, specifically Occupy Janis states:

"I saw a lot of that at Occupy and it created huge divisions and huge political problems because all of the sudden there was money and there were too many people involved to use that consensus model to manage it and things got ugly."

The lack of input in the decision to serve white bread may not seem as paramount or threatening as appointing a movement "accountant", but in either case lacking transparency is perceived as being incompatible with direct democracy and thus incompatible with the movement. In order to further enhance democracy within the movement, Portland FNB also practices consensus-based decision making. In this case, decisions are finalized only when all participants agree in the decision making. This can result in a very pro-longed decision making process which participants highlighted as 
being inefficient at times. Janis, due to the amount of time reaching consensus can take, jokingly said:

"That's probably why they invented hierarchy in the first place because consensus is not always efficient and in our society where it's efficiency, efficiency, production, production, instant gratification, return on investment, (and) consistency. It's hard to use a direct democracy sort of model....”

Another interviewee reported that consensus based decision-making can result in what she calls "endless processing" and that it is unnecessary to have "five meetings about where the turmeric needs to go in the kitchen”. Despite the understanding that consensus based decision-making can result in a complex process stemming from the most mundane of decisions, the purposeful use of it is important as it illustrates the movement's dedication to operating as an alternative organizational model. The quotation from Janis clearly illustrates this, as inclusiveness and empowerment is valued over efficiency, instant gratification, and other words typically associated with economic activity. John's reification that this type of decision-making is an essential part of operating as an alternative model that rejects the status quo illuminates another important piece of FNB:

"You and whatever people you want can create your own systems of accountability and do that at the community level. It's really just a rethinking of power dynamics and dynamics of oppression and privilege."

All the interviewees mentioned community and often community building as a long-term goal of Portland FNB. The term community is very subjective and understandings can vary greatly. However, those involved with Portland FNB understood community to be more holistic, often involving various communities. 


\section{Creating Communities with Food, Not Bombs}

As illustrated, at the core of Portland FNB lies the "bottom-liners". These individuals are responsible for sustaining the movement and reinforcing the practices associated with operating as an alternative organizational model. The core membership of Portland FNB is a close-knit social network comprised of strong, personal relationships. This could be seen as being completely detrimental but the practice of direct democratic, consensus based decision making, is understood to offset this to some degree and result in increased levels of solidarity amongst a wider swath of individuals. Kurt emphasizes this belief by stating that consensus-based decision making does "build further community and I think comradery...” This implies that having one’s input recognized and accounted for results in one feeling like a part of the movement. In addition to utilizing practices that positively reinforce participation, Portland FNB does not have requirements in terms of who can participate in movement activities and claim FNB “membership”. After hearing FNB participants mention community numerous times, I asked Paul during his interview to define how he understands community within Portland FNB. He provided this definition:

“I mean it's just that there's a social bond between people. They are mutually attracted to working together. It's not like someone pushed them together. We didn't say "Hey! Fucking you got to be part of our club or buy our literature or ideological shit storm. You just show up and have fun."

The lack of coercion and formal power within Portland FNB is understood to allow individuals to freely associate with one another. Despite the institutionalization of certain values, one is not required to self-identify with a particular identity to participate in the organization. Rather, nearly all the participants understood community building efforts to extend to those not identified as “activists”. Within the Downtown cell, 
building social capital with the homeless population is prioritized more so than in the Inner SE cell. Before being located downtown, the Downtown cell was preparing food at a church in East Portland. The church became worried that FNB was not properly licensed to use a commercial kitchen and decided to rescind their permission to use space. As a result, the Downtown cell approached a homeless advocacy group that has a formal encampment with permission from the owner, on an empty lot in downtown Portland. John stated the move as something that just "makes sense”. He further elaborated upon this as he acknowledged how those at Right to Dream Too felt about the collaboration:

"It feels more like...people at Right to Dream Too have said it. This feels like solidarity. It's like we're building solidarity. We're not in some kitchen somewhere we're out in....almost right where we are serving. We're like three blocks away from where we're serving, cooking, able to share food and share resources with an amazing group that's doing amazing work for houseless advocacy.”

A popular motto of FNB is "Solidarity Not Charity”, illustrating an understanding that the movement is significantly different in comparison to traditional nongovernmental organizations. Pete best exemplifies this by explaining that the meal servings are not "just a food line where you can go anywhere in town. There's a whole message behind this stuff.” The meal servings are understood to be a political action calling attention to social problems and the physical meal is simply a medium through which to do that. The desire to build social capital was seen to be absent from the traditional soup kitchen atmosphere. Those within FNB expressed concern that soup lines had "expectations" from the homeless. This was typically explained to be the acceptance of a religious doctrine and its corresponding teachings in exchange for a meal. Lauryn aptly summarizes this understanding by explaining that: 
“A lot of soup kitchens and places you would get food boxes, you can only go so many times. You can only take so much. You're limited and also judged. I’ve been through it a lot. No matter how caring and giving an organization wants to be few are able to drop those judgments and fixed ideas and really just be there with people...."

Lauryn offers a unique and insightful perspective as she has experienced homelessness firsthand. It should also be noted that Paul has also been homeless for a period of time. Both of these participants first became acquainted with FNB by attending a meal serving in the geographic location they were living in at the time. Although I cannot make claims regarding the "success" of FNB in combating homelessness, Portland FNB does seem to garner more active participation from those of the homeless community. Oftentimes upon arriving at the MAX station in downtown Portland at approximately 6:30 p.m., the same individuals would be waiting near the serving site. These individuals would then help unload the bike trailers and lay out the foodstuffs along the sidewalk. Both Janis and John expressed deep satisfaction at recognizing and knowing individuals who come to the meal serving on a weekly basis on a personal level. The following quotation from Janis captures this brilliantly:

"...they ask us about our kids and we ask them about their health thing they are going through and how they are weathering it or this woman who is in a legal battle with her landlord. It gives them someone to talk about those things that I'm not sure they would have otherwise. So there's a social reciprocation too that's really positive.”

The exchange between FNB participants and members of the homeless community is seen to be mutually beneficial for both parties involved. This is at the root of understanding FNB to be a community builder rather than simply a meal supplier, as John expressed his disdain of soup kitchens stating, "You go in. They herd you out.” The Portland FNB meal servings construct a space in which individuals from various 
communities can engage with one another. As an organizational model, Portland FNB is understood to operate differently within the urban landscape due to a relationship that is seen as being mutually beneficial.

\section{Attempting to Spread an Alternative Model}

Within Portland FNB, participants understand that either cell cannot grow indefinitely without contradicting the larger values embraced by FNB as a movement. Decentralization is necessary for each cell or chapter of FNB to remain autonomous and small enough to continue to practice direct democracy and consensus based decision making. The growth of one cell would seem to inevitably result in the need for centralized, formal authority. Paul described the way FNB grows as:

"Plus there's the aspect of the...it's sort of like a bacterial growth in a way. It kind of festers in one area and then other people get really interested and then they spilt off and multiply on their own."

Ideally, interviewees envisioned FNB chapters littering Portland. In their interviews, Pete and Kurt noted that the preferred number of servings per week would be between five and seven but there is simply not enough people, time or energy to conduct that number. Through the dispersion of knowledge, the use of direct democracy, and the reliance on reaching consensus, individuals are gradually trained to at the very least sustain the current Portland FNB organizational model. A perfect example of this is Robert from the Inner SE cell. Robert initially waited months to be able to conduct his first pick-up and by the time I interviewed him, he had been told he was responsible for keeping the Inner SE cell alive over the past winter. During the winter, several interviewees mentioned that participation from outside the core group of activists drops significantly. 
The responsibility of maintaining the meal servings rest solely on the shoulders of the "bottom-liners". Irrespective of season, the core group of participants expend an extreme amount of time and effort in order to sustain the movement and several interviewees expressed a desire for a larger base of participants to draw upon. This would allow them to step away and take a short break. Pete captures this sentiment as he states:

"If I wasn't here being one of the main people I think it would be harder for them to get more included. So it's good to have veteran people that have been around for a while to talk and get involved with and then they can take over and plug-in more and I can take breaks. That's kind of one thing I would like to do more a little bit of. Not do it almost every Tuesday.”

At a minimum, the time commitment required to participate solely in the cooking and serving process is five hours. As Pete regularly participates in the pick-up on Tuesday, in addition to cooking/serving, this can easily become an eight hour day for him. "Burn-out" is a primary concern within the core group and "activist" community. The possibility of losing motivation can lead to permanently walking away from the movement. This places the movement in precarious situation as "growth" is desired, but it cannot result in agglomeration. Coinciding with the concern of burn-out amongst bottom-liners was the belief that the meal serving, especially that of the Inner SE cell, continued to draw from the chapters extended network and was not branching out to other populations. Carol expressed her frustration by noting:

"I feel like we've done these things successfully in Colonel Summers Park but I wonder how much we're just giving free food to our...to our extended family of friends and I would like to see more people who come on a regular basis particularly from the non-houseless community who get in their cars and drive there with their little containers and their grocery bags..."

Carol's frustration directly correlates with Pete's description of Portland FNB.

The movement has difficulty "recruiting" individuals from the larger community. This 
however does not go unacknowledged and rather is a source of irritation for many FNB participants. Aretha described that ideally she would like Portland FNB to be a "resource for different communities and more communities” in Portland. A major barrier hindering the growth of FNB within Portland is the privileged status of having time to participate in the weekly meal servings. The movement dispersing was overwhelmingly understood to be positive, but this growth could not rest upon those already involved heavily within the movement. Hence, the movement must grow by distributing the necessary institutional knowledge to new participants and incorporate practices that promote leadership in the belief that the movement will disperse outwards.

\section{The Vision of Portland FNB}

Nearly all participants expressed a desire for systemic structural change, although their understandings of Portland FNB's level of success in achieving this, greatly varied. Janis called the movement's impact a "drop in the bucket" and acknowledged that the serving of healthy and nutritious meals is not going to radically alter the way the city treats the homeless population or end homelessness. However, she did understand the activities of Portland FNB to be addressing a gap that is left unaddressed by other institutions, such as non-profit organizations due to financial restraints. Other participants understood the movement to be an exemplar of a different lifestyle outside the dominant culture. Robert best embodies this understanding:

“...you can eat much better for cheaper and all other areas of your life, all your other needs, for clothes, for bicycles, tools, machines. You can do all of that together in a group and it becomes much cheaper much easier for everyone overall and you get a better life that you might not tell might not recognize that you will get that right now but when you start doing that you'll see that that is the case.” 
Robert understands Portland FNB to promote cooperation, making it possible to exit the larger economy. Earlier in the interview, he explained how he felt dominant society enforces a material standard of living that is unsustainable for both individuals and the environment. Portland FNB is providing a social network to "opt into" and an example of how individuals can provide and rely on one another for basic needs, at the community level. Paul reiterates this sentiment, although not as explicitly, when he explained that opening his apartment to Portland FNB just “made sense" and was "practical". When asked for further detail, he cited that his apartment is very close to the serving site and the servings eliminate a portion of waste that is created by the current model of food production and distribution. Both Janis and Aretha expressed a desire for Portland FNB to grow its own produce rather than relying on donations that could possibly stop flowing. The desire of Portland FNB participants to grow their own food indicate further attempts to become autonomous and move beyond capital (Böhm et al. 2010).

Overall, interviewees understood the meal serving to embody the larger dynamics that Portland FNB would like to see implemented within larger society. In this sense, Portland FNB can be characterized as a prefigurative SMO, as the organization reflects the broader principles and dynamics it seeks to implement. Janis described the meal servings as follows:

"Just people who wouldn't necessarily be in one place gathering and peacefully sharing a resource and people who may have not gotten to know each other any other way conversing and meeting one another and I think that's a microcosm of what the organization would like to see in the world is people sort of setting their prejudices aside and meeting one another and talking for real and trying to solve problems in non-violent ways..." 
The production of safe space by Portland FNB ensures that individuals who may not otherwise interact with one another, can meet and discuss freely and openly. During my time in the field, I have seen those utilizing the meal serving, discuss a wide range of issues ranging from bike repair to municipal elections. The meal serving sites, in addition to providing a basic necessity in the form of food, provide a space in which social capital along with community can be cultivated. However, serving meals in public is met with resistance from both city authorities and private entities, as the democratic ideals envisioned and practiced by Portland FNB clash with neoliberal policies, creating a scenario of constant negotiation, which will be the focus of the following chapter.

\section{Conclusion}

In this chapter I provided a brief history of the FNB movement, locating it in the larger context of radical social movements and the food justice movement in particular. Coinciding with strands of NSM theory, Portland FNB is loosely structured and nonhierarchical (Buechler 2000; Melucci 1980). Within Portland FNB, operating without hierarchy is not synonymous with a lack of leadership and rather the facilitation of leadership occurs in a space where power, authority and coercion are emphatically resisted. Through the distribution of institutional knowledge and strategic tactics, such as direct democracy and consensus based decision-making the movement, those most invested in the SMO attempt to create conditions for movement dispersion.

Decentralization limits the way in which Portland FNB can grow, as the organization must grow outward with individuals splitting off, in order to start new cells. Respondents also understood decentralization to help in maintaining transparency within the 
organization. Portland FNB must remain small in order to be able to effectively practice consensus based decision-making.

The organizational structure of Portland FNB reflects values and principles such as anti-authoritarianism, egalitarianism, transparency, and democracy. Through repetitive processes, individuals construct a shared meaning of these values and principles that are then actualized by the chapters at large. The organizational structure of Portland FNB influences the strategy the organization utilizes as well. In the following chapter, I will argue that through the colonization of public space Portland FNB further extends the values and practices listed above to the public sphere. By asserting that access to healthy and nutritious food is a right, along with the ability to actively engage with producing the city, Portland FNB is redefining urbanity in terms of democracy and egalitarianism. 


\section{CHAPTER V: THE COLONIZATION OF PUBLIC SPACE}

\section{Overview}

In the previous chapter, I argued that Portland FNB employs an alternative organizational model that enables participants to practice values that oppose top-down power relations and market reliance. For example, instances where the importance of transparency is emphasized and leadership is actively dispersed outwards indicate the type of dynamics Portland FNB would like to see instituted within larger society. In this chapter, I explore the following research question: How is Portland FNB's use of public space reflective of its organizational dynamics and principles? By building upon previous findings, in this chapter I suggest that Portland FNB further extends and attempts to enact alternative models of political engagement by directly challenging what is considered public and what type of activity is deemed appropriate within public space. I argue that FNB's proactive colonization of public space asserts that civic engagement along with food, is indeed a right to be shared by all. However, the proactive colonization of public space has become increasingly difficult as the definition of public space is constantly being redefined.

In what follows, I first lay out a conceptual framework in which Portland FNB can be placed. Concepts related to urban space and its possibility for social change are discussed. Then, by utilizing interview data, I examine how interviewees understand Portland FNB to be "filling" a gap by providing access to healthy and nutritious for the homeless population. By filling this gap, Portland FNB is drawing attention to the lack of state funding for social goods. Third, I explore how public space is regulated in various geographic locations through the use of specific FNB chapters’ websites. Finally, I 
recount the resistance Portland FNB has experienced while serving meals in public space within Portland in an effort to reclaim public space for collective use. This attempt to reclaim public space helps to build a more inclusive community while visibly resisting neoliberal economic and political policies.

\section{Survival in the City: Space and Place in a Neoliberal Era}

As Portland FNB is committed to engaging in direct action, space for meal servings is vital to the operation of the SMO. The utilization of public space not only serves a functional purpose, but more importantly, it allows Portland FNB to practice and extend their values to the public sphere. Portland FNB opposes the exclusion of the homeless within the city by constructing a more just and inclusive space that emphasizes community and embodies the values associated with FNB. Upon arriving at the designated serving site, the FNB banner is typically hung in some manner. It serves as a centerpiece, establishing that this space is now currently occupied by Portland FNB. The food itself, is placed in a row along the ground. The large hotel pots and pans stay stationary throughout the serving. Before the food is distributed, typically John (Downtown cell) and Aretha (Inner SE cell) shout “Food Not Bombs”, indicating the serving to start. Those utilizing the meal serving, often cluster in close vicinity to the banner/food, to eat their meal. This colonization of space asserts that the "right to the city” is indeed a human right, while also demonstrating a more just and equal society is possible.

The notion of the right to the city is accredited to French scholar Henri Lefebvre (1968). Lefebvre originated "the right to the city" as a term to encapsulate the complex dimensions of a desired radical transformation of the urban environment. He labeled the 
term both a "cry and demand" and it has become a rallying point for various urban social justice movements prioritizing issues such as housing rights, living wages, etc. (Mitchell and Heynen 2009:616). Lefebvre defined the city as:

"... and thus the city is an oeuvre, closer to a work of art than to a simple material product. If there is production of the city, and social relations in the city, it is a production and reproduction of human beings by human beings, rather than a production of objects (1996:101).”

Lefebvre conceptualized the city as a site for the production and reproduction of social relations, rather than a site dedicated to the creation of material objects. In this conceptualization, the importance of social relationships are emphasized over that of economic relations. Mitchell and Heynen (2009) argue that the right to the city goes beyond merely "habiting” the city but includes “inhabiting” it as well (615-616). The two principal rights of individuals inhabiting the city include; the right to participate in producing space and the right to appropriate it. The right to participate refers to the ability of inhabitants to engage in the decision making process. Inhabitants must play an active and central role in decisions that produce the city rather than participating in production through indirect means. The right to appropriate refers to the ability to access urban space in addition to manipulating and transforming it in order to meet one's needs (Purcell 2002:102-103). As contemporary urban space could be labeled as inadequate in meeting the needs of all, the appropriation of urban space is often necessary.

As the neoliberal state is structured on a rational economic basis, FNB challenges this order not only through their organizational model, but also through the appropriation of public space and decommodification of food (2009:1233). The serving of free meals to the public creates a “socially embedded, decommodified circuit”, which John Vail defines as "any form of economic activity (broadly defined) that influences and reorients 
the motivations, incentives, interests, values, priorities, and behavior of economic actors to promote social priorities and egalitarian objectives rather than market rationality” (2010:329). FNB produces a space that not only is politically and socially inclusive, but also reorganizes economic activity to be illustrative of desired social relations. With this conceptual framework in mind, it is then possible to analyze FNB and Portland FNB more specifically.

\section{Filling in the Gaps: Providing Healthy and Nutritious Food}

Interviewees from the Downtown cell emphasized the importance of their work as access to healthy and nutritious food, along with an extended social network, is virtually non-existent for homeless individuals. Homeless individuals have been effectively cutout of the market financially. The Downtown cell serving site is in close proximity to other soup kitchens, missions and social services. Meals are available at these locations but the type of food that is served is extremely different from that of a FNB serving. Janis understood the homeless population to be extremely vulnerable in terms of mental and physical health and thus emphasized the need for "healthy food". Similarly, John also mentioned the "benefits" of healthy food and the lack thereof by exclaiming:

“...and are able even if they only get it one day a week are able to see benefits from obtaining that. I think that even just one day a week it's like people deserve to have access and this is the one way...again through doing soup kitchens and food banks there's opportunities to get healthy fresh food here and there but it's very slim usually..."

Along with preconceived judgements, not having access to healthy and nutritious food is seen as a shortcoming of other institutions providing services. John and Janis acknowledged this, but also understood these institutions to be financially constrained. The increased need in emergency food aid and homelessness rates in select large U.S. 
municipalities illustrates a clear lack of funding and available space for shelter (Resnikoff 2014). Numerous interviewees associated the need for healthy food with an understanding of increased prevalence of mental health issues among the homeless. Janis noted that she believed limited access to nutritious food is the "biggest thing lacking in truly making effective transitional services.” As food is commodified, purchasing "healthy and nutritious" food is virtually impossible for the homeless. Combine this with ordinances outlawing the use of a stove or open flame in public and the cooking of a meal becomes nearly impossible. Pete referred to the meal obtained at the Downtown serving as "the best meal" many people consume during the week. A majority of respondents felt the food provided by missions and soup kitchens was too heavily processed and therefore inadequate for a vulnerable population to consume. In reference to the population the Downtown cell serves, Janis commented:

“...because the population that we serve is...we're actually filling a real gap. It's not a picnic in the park its people who really would go hungry and some people say, 'Oh shoot I haven't eaten in three days' and they have two big helpings."

Portland FNB constructs an urban landscape with an increased ability to provide access to healthy and nutritious food immediately. Although this urban alteration is not permanent, it does provide an extended time period in which the harsh realities of homelessness are not pushed to the fringes of the urban landscape but rather placed at the forefront of the city. By remaking space and serving meals, interviewees felt that they were immediately making an impact on the daily livelihoods of those utilizing the meal serving. Individuals were either in immediate need of sustenance or through the sharing of information and ideas, they were able to make more long-term changes. 
In regards to long term change, Portland FNB interviewees had very pragmatic views on the impact FNB is having. Nearly all participants understood Portland FNB to have a small, but real impact at the local level. In addition to building community, the meal servings help to create a space in which information can be transferred from person to person. This transfer of knowledge, information and ideas was seen as being correlated to positive change. John acknowledged the following:

"Sometimes...there have been times where it's taken me months to like realize that people who have been coming...the same faces have been coming back to our dinners. I've seen people come back to our dinners who have come to me and been like you know the food that you serve that you've given to me has inspired me to eat healthier to find healthier options even living on the streets."

Ideally, several Portland FNB participants stated that the servings would stimulate both dietary change and changes in worldview. In this case, Downtown cell participants and those utilizing the serving are able to produce a shared meaning of "healthy food" that would not be possible without the construction of a safe space. In addition to the desired change in diet, the excerpt above also indicates that the meal servings are effective in drawing individuals back on a consistent basis. While this may not be an "indicator of success", it does illustrate that Portland FNB may be successful to some degree in building community.

\section{A City Regulated: The Retraction of Public Space}

Globally, FNB chapters are located primarily within urban areas. With a brief examination of the FNB website, one can locate chapters in cities from Bogota, Columbia, to Paris, France. Meal servings typically occur in public parks or squares, as this space is often the most easily accessible and open to all. However, as public space is increasingly regulated, serving meals in public has become extremely difficult in some 
cases. For example, the Southampton chapter of FNB (United Kingdom) has noted the potential for the Anti-social Behaviour, Crime and Policing Act 2014 to disrupt meal servings. This act enables individuals deemed to be a "nuisance or annoyance" by private property owners, to be subject to penalty. As public space often borders private space, this act could have severe ramifications. The act above is an example of what could be considered the criminalization of homelessness. The law does not explicitly outlaw the state of being homeless but it does restrict who can occupy public space. The term “criminalization of homelessness” refers to a variety of measures that regulate who and what can be done in public space.

These measures often disrupt one’s livelihood as “life-sustaining activities” such as the sharing of food in public, panhandling, using a temporary shelter, etc. are often prohibited. For example, according to the National Coalition for the Homeless (2014), $27 \%$ of US cities ban sleeping in specific areas, such as public parks. The following excerpt from the Pittsburgh FNB chapter's website illustrates the chapter's specific view of the contemporary urban landscape:

"We see how our city violently attacks those who are dis-enfranchised, we see them trying to remove "un-desireables" from Market Square, we see how they set up so called "Safety Ambassadors", and how it is just a way for them to make money, (and) we see how they want to move public transportation away from downtown..."

The excerpt above, highlights the contested conceptualization of what is public, who can freely access it, and what is deemed appropriate within it. The use of the term "un-desirables” illustrates that segments of the population are seen as being unfit for specific areas. In this case, being visible is inappropriate for the "un-desireables" and 
therefore these individuals must be ushered onwards. John described the precarious urban environment marginalized populations exist in as he stated the following:

“...it's a lot of the issue I think with people living on the street and people in any marginalized position in society is that invisibility. That a lot of times people are treated like they are invisible. People who live on the streets are treated like they're invisible, like they're lesser."

These comments encapsulate the push for the homeless and other marginalized populations to remain out of the public eye. This "push" is often in form of legal ordinances that not only deny individuals the right to produce and appropriate space, but also temporarily occupy it. This privatization of public space has made it increasingly difficult to challenge global corporatization and neoliberalism. For example, the occupation of Zuccotti Park (NYC) by Occupy Wall Street protestors, was subject to expulsion after being deemed a "health and fire safety hazard" by Mayor Bloomberg on behalf of Brookfield Properties, the park’s private owner.

Legally, Zuccotti Park is to be accessible to the public for "passive recreation”, twenty-four hours per day, yet this case illustrates how the subjective interpretation of "passive recreation” can be used to quell social protest. Mayor Bloomberg argued, the occupation of the park by protesters was effectively limiting access to the greater public and therefore occupation was in violation of the law (Barron and Moynihan 2011). In addition to the seizing of public space by Occupy, the importance of reclaiming public space for protest is evident by the Arab Spring protests and Hong Kong’s Umbrella Revolution. In either case, the reclamation of public space, in the form of squares and other entities, was undertaken in order to protest the current state of politics. Similar trends can observed within Portland, as engaging in direct action increasingly hinges on utilizing contested space. The privatization and regulation of public space inevitably 
impacts Portland FNB, as both cells are forced to operate within an unstable and contradictory urban landscape.

\section{The Experience of the Downtown Cell: The Efforts of FNB to Reclaim Public Space}

Before securing the current preparation space at Right to Dream Too and serving space at a public transit station, the Downtown Portland cell had a tumultuous and difficult time securing a stable space for the meal serving. The cell was consistently being pushed from location to location by the city through legal means. This push was often subtle as outright resistance such as arrest, disruptions of servings, etc. did not occur. Depending on the location of the serving, the city utilized different strategies. The city often passed ordinances that made it extremely difficult to conduct meal servings. The use of public space became highly regulated or not possible due to the fencing off of public space. The threat of arrest was often used to intimidate those involved with the Downtown cell, creating an unwelcoming environment to say the least.

Initially, after the dissolution of Occupy Portland, the Downtown cell was serving meals in front of City Hall. The motivation for selecting this site was primarily political, as it was meant to protest the "camping" ban in Portland. Within Portland, a public order specifically, 14A.50.020 Camping Prohibited on Public Property and Public Rights of Way, outlaws "camping" in or upon any public property or public right of way. The order defines the act of "camping" as an attempt "to set up, or to remain in or at a campsite, for the purpose of establishing or maintaining a temporary place to live”. The order further defines a campsite as “any place where any bedding, sleeping bag, or other sleeping matter, or any stove or fire is placed, established, or maintained, whether or not such 
place incorporates the use of any tent, lean-to, shack, or any other structure, or any vehicle or part thereof” (Auditor’s Office, City of Portland).

This ordinance not only restricts activities necessary for survival (eating, sleeping, etc.), but also invites selective regulation from the authorities. The subjectivity of words such as "established” and “maintained”, creates a situation where the determination of legality is based upon individual interpretations. Similar to the creation of an unstable urban landscape, this ordinance creates as unstable legal landscape. Wherein, similar situations may result in different outcomes, with individuals possibly being arrested in one case and warned in another. While providing meals to individuals protesting this city ordinance, outside City Hall, the Downtown cell experienced firsthand how an ordinance such as the one above can complicate the process of serving meals. John described the space in front of City Hall as being very desirable due to the high level of visibility but ultimately too difficult to use due to legal restrictions. He stated:

“The drawbacks from that space and every other space that we've been in besides the space we're in right now is that we had no coverage and we weren't allowed to put up... unless you get a permit which costs a good deal of money and you have pay for week after week and we weren’t going to do that you can't put up a tent without a permit you can’t put up any kind of tarp or anything without a permit.”

The difficulties associated with using the space in front of City Hall expressed in the excerpt above are two-fold. First, the use of financial capital to secure access to public space is antithetical to the values of FNB as an SMO. In general, FNB does not seek permission from authorities or local governments to use public space. Secondly, the process of "obtaining” a permit and the expense associated with it essentially forces FNB participants to operate without some form of shelter from the physical elements. This of course results in a situation where individuals utilizing the meal serving must also face 
the elements, resulting in fewer meals being served, particularly during the winter months. John also described that the weather takes a toll on those heavily involved with the Downtown cell but they were "hardcore" enough to continue to serve outside if need be. Despite this restriction, the meal servings continued for a brief period of time until the city took further steps in order to pressure the Downtown cell into moving the meal serving.

Both John and Janis, explained that the city passed a "sit/lie" ordinance, declaring the one-block area around City Hall to be a "high-traffic" zone from 8:00 a.m. to 9:00 p.m. John explained that this essentially outlawed being stationary and that FNB participants would have to constantly be in motion during meal servings. Rather than completely restricting access to the space around City Hall from the outset, the city passed successive ordinances that made it increasingly difficult to utilize the space itself. Janis summarized the effect of the sit-lie on the Downtown cell as follows:

“...that was ultimately their way of shutting down and telling FNB 'Well you can't have a bike trailer, you can't stand here, you can't park your bike over there' and constantly changing the rules and making them jump through all these hoops and just making it really difficult to keep feeding people.”

The excerpt above illustrates the ability of the state to be reflexive and adaptable within a legal framework, as site-specific ordinances can be enacted quickly if so desired. This makes serving the homeless and hungry (others as well) extremely difficult as spaces can be deemed to be inappropriate for use at any given time. The constant defining and redefining of what space qualifies as public, creates an unstable urban landscape for Portland FNB. Janis further explained that she felt the city perceived the Downtown cell as "enabling" the protestors through the provision of free meals and thus the meal servings needed to be discontinued. Eventually those heavily involved in the Downtown 
cell were threatened with being arrested, which effectively disbanded the serving at City Hall. John explained that at the time he felt it was "not a battle worth fighting" and that moving the serving was the preferred option. Post-City Hall, the Downtown cell followed those that were camping outside of City Hall, first to Chapman Square and then to Terry Schrunk Plaza. In either case both spaces were fenced off soon after for various reasons and the Downtown cell was forced to find a new serving location.

\section{The Struggle of Making the Meal Serving Visible}

Before settling on the public transit station site, the Downtown cell attempted to use Ira Keller Plaza for meal servings. This serving site did not garner resistance from the city, but it also did not draw a substantial number of individuals utilizing the meal serving so it was abandoned. John explained this transitory stage as:

"Then we moved to Ira Keller Park but nobody was coming up there to eat because it was way far away. It was not very visible and eventually we went there one week and there were like five people and we were like, 'no more of this' so we decided to move under the Burnside Bridge.”

The desire to be visible places Portland FNB in a compromising position. The meal serving site must be visible enough to warrant a sense of effectiveness, while the placement must be located in space where the sharing of meals is considered appropriate. The meal serving is designed to draw participation from the larger population, but increased attention can derail an entire FNB cell's efforts. The Inner SE cell has experienced this firsthand as access to the park's pavilion where their meal serving is held, was almost completely lost. During the summer of 2013, residents around Colonel Summers Park began to complain to the city about the activities occurring at the park. The Inner SE cell's servings coincide with "Monday Funday”. This "event” draws a large 
number of individuals, the majority of which do associate with the Inner SE cell. Individuals primarily congregate in the grass and socialize with one another. Although these complaints were not directed at the Inner SE cell, the proposed solution would have greatly impacted the ability to conduct the serving.

During this time, the Portland Parks and Recreation contemplated fencing off the pavilion, as the park was considered to be a problem area due to underage drinking, illicit drug use, and vandalism. The Portland Parks and Recreation stated that the activities of the SE cell were in no way connected to the possible fence-off and that they fully supported the meal servings being held in the park. In addition to the possible fencing off of the pavilion, the number of park ranger patrols increased (Vanderhart 2013). This increase in surveillance was viewed unfavorably by FNB participants and believed to be extremely unnecessary. The following excerpt from Paul highlights the perceived absurdity of these increased patrols:

“...from the spring until about the end of the summer we had like cops watching us and forest rangers standing behind us with their four wheelers and stuff. Like constantly watching us serve. I'm like do you want me to throw a tomato? What are you waiting for? It's not hurting anybody. Just leave us alone..."

Eventually the presence of park rangers at the Inner SE cell's meal serving disappeared, but only after a concerted political effort from those involved with the Inner SE cell. FNB participants attended meetings and testified in front of city officials. Janis acknowledged that a few participants that were heavily involved with Portland FNB were able to "win over" some of the individuals that originally supported the pavilion being fenced off. Additionally, Paul noted that participants from the Inner SE cell have had discussions with a particular city commissioner regarding the meal servings occurring in Colonel Summers Park, gaining her support as well. Eventually the discussion regarding 
the fencing off of the pavilion was abandoned. Losing the pavilion would have been detrimental to the Inner SE cell, especially in the winter. During periods of heavy rain, nearly all those engaged in the meal serving cram under the pavilion. During these times, individuals are often forced to interact with one another as personal space is at a minimum.

Remnants from the period of increased surveillance still exist however. At Colonel Summers Park, there are two restrooms side-by-side. During my field work, I routinely observed a park ranger arriving approximately between 6:30 p.m. and 7:00 p.m. during the Monday serving. The park ranger would then wait until either bathroom was empty and then promptly lock it, repeating the process with the other. The Portland Parks and Recreation website states Colonel Summers Park hours are from 5:00 a.m. to 10:00 p.m. This created a situation where restroom facilities were not available to everyone at the park, those associated with the Inner SE cell included. At the very least, the locking of bathrooms is a minor inconvenience as the serving typically lasts for 2-2.5 hours and it is not unreasonable that the restroom would need to be used. Carol understood the locking of the bathroom doors to create more work for those heavily invested in the cell. She stated the following:

"You know if everybody washed their own dishes that would great but you got to make sure everything is sanitized and the park doesn't help because they lock the bathroom doors after a certain time so that's not helpful."

The locking of the bathroom doors may not severely affect the Inner SE cell participants because interviewees have the option to travel back to Paul's apartment and use the restroom. However, those utilizing the meal serving do not have this option and the ability to survive within an urban environment is hindered. It is reasonable to assume 
that individuals eating a meal would have to use the restroom facilities at some point.

From my observations, the locking of the bathroom doors did not decrease the amount of activity in the park, but rather created an inconvenience to those involved in the meal, serving or eating. Additionally, the locking of the bathroom doors further indicates how an already marginalized population is further excluded from engaging in life-sustaining activities. The threat of closing off the pavilion seems to have been quelled and with the exception of the bathrooms being locked, the Inner SE cell's serving occurred unimpeded. This is not the case with the Downtown cell as FNB participants often come into contact with private entities during disputes over property boundaries.

\section{An Interstitial Existence: Stuck Between the City and a Private Entity}

The current location of the Downtown serving is one of contestation as the serving borders city property on one side and private property on the other. In terms of regulation, the serving site is interstitially located, as it is subject to different stipulations. The private property is subject to surveillance by private security officers that often "find" something out of place during the meal serving. Janis explains the interstitial existence of the Downtown cell serving as:

"The sidewalk is spilt in half. Half of it is Trimet transit property and we're not allowed to serve or store any of our stuff on there. There's this narrow city sidewalk which we're not allowed to block and we have to always have a 36 inch space for people to go by which doesn't leave a lot space for our bikes or our bodies or our pots and pans and then right behind that is private property that is controlled by private security services that don't care for us."

The narrow strip of sidewalk, used by the Downtown cell, is space in which organizational activities can be practiced safely. Extending past these boundaries results in selective regulation. Pete described the attention from the private security as 
harassment but also noted that it did not amount to a significant issue as it did not derail the meal servings. During my time in the field, it quickly became apparent that the boundaries between public and private space were easily blurred and seemingly up for debate on any given day. In particular, the parking lot located behind the meal serving is a point of contention between the Downtown cell and private security. Interviewees often lean their bikes/trailers against large concrete pillars. On at least two occasions, I observed the security officer that was patrolling the grounds, ask the FNB participants to move their bikes and trailers off the property. This did not cause any larger issues as the interactions were often cordial and interviewees quickly moved their belongings. However, on a separate occasion the security officer's request directly clashed with the cell's values. The excerpt from my field notes below illustrates an example of this.

"Upon arriving at the serving site (Downtown), John begins to unpack the banner from bike. The Downtown cell regularly hangs a large FNB banner across the poles located on the sidewalk to symbolize that they are part of a larger SMO. The banner consists of the words "Food Not Bombs" and depicts a clenched fist raising a carrot in the air. As John began to hang the banner up a security guard approached him and began talking with him. I was out of earshot and could not hear the full discussion. I saw John shake hands with the security guard and the guard left. I approached John and asked him what they had talked about. John told me the security guard had asked him to remove the banner, saying that it "would be best if the banner was not hung up". John told me, he responded by telling the security guard that he knew the law and the sidewalk is public property. The security guard did not return at any other point during the serving."

Although this incident may seem minor, it provides further insight into how

public space is regulated. This regulation of public space infringes on the ability of the Downtown cell to be visible, as the banner symbolizes that the cell is part of a larger SMO. I often observed individuals asking the servers what was occurring and if they were part of a larger organization. Downtown participants routinely directed individuals 
towards the banner in their response. The Downtown cell is located in between two separate entities and therefore shares a "border" with both the city and a private party. In this instance, the debate not only revolves around what space is public, but where does the public space end and the private space begin, as crossing the boundary can become a point of debate and contention. Currently, the Downtown cell benefits from the support of the city with TriMet acknowledging that meal serving can legally take place on the narrow strip of public property. Portland FNB goes beyond occupying public space as they transform it into a space where survival activities are supported and the values of FNB are able to be practiced.

\section{Creating a Community through the Colonization of Public Space}

Portland FNB is able to access space and transform it by publicly sharing food, as no city ordinance exists that makes the sharing of food illegal. Numerous interviewees acknowledged that Portland FNB is better off than other FNB chapters because of this. Despite the struggles Portland FNB encounters, both cells are effective in maintaining a weekly meal serving. These weekly meal servings become sites in which healthy and nutritious food can be eaten in a safe and welcoming space. Pete explained the rationale behind serving food as:

"Well everybody has to eat. That's one thing. Everybody has to eat. It's kind of a good reminder it's like one the three basic core... water or maybe food/water is one, shelter, community. Those are three pillars without that you're kind of hosed.”

The excerpt above alludes to an important point: community and food often coalesce within the context of Portland FNB. Portland FNB provides both food and a larger community to those who may be treated as "invisible” and "lesser". The serving of 
meals in public space is meant to minimize barriers to participation and increase inclusiveness. For a short period of time Portland FNB transforms public space into a space for survival. No longer is public space an area to meander and move through, but it becomes a space where activities necessary for survival can occur largely unimpeded (Mitchell and Heynen 2013). The use of the sidewalk by the Downtown FNB cell illustrates this perfectly. Individuals "loitering” at the transit station are typically waiting for their train but on the night of meal servings, individuals gather to share a meal with one another homeless or not.

Lauryn described the Monday serving as a place for people to “...go and connect.” Further stating that, “When you're sharing something as basic as food it goes beyond all divisions.” The meal serving serves as a transformed space, where divisions are actively de-produced, while egalitarian social relations are reproduced. Kurt explained, that the meal serving is a place of acceptance as he stated:

"I have seen some of the most compassionate oriented giving and exchanges during those FNB. It wasn’t just, “Hey how are you? Please move along.” It was, "Hey let's spend a moment really..." even if it's just a moment understanding that we're doing this act of kindness together."

At all servings, individuals do not serve themselves, with those most heavily involved in Portland FNB alternating the role of server. It is almost taboo for an individual to serve themselves and this only occurs at the very tail-end of the serving. This practice creates a short period of time where individuals can interact with another and from my observations, often do. This action relays symbolic meaning as it is indicative of the desire to be inclusive. The meal serving provides an opportunity to collectively engage in an act necessary for living; eating. It also creates opportunities for interaction between FNB participants and individuals from marginalized populations. 
Paul acknowledges the success of Portland FNB in terms of providing community to marginalized individuals, as he stated:

"It's just a little thing that we do but at the same time we recycle probably.... 1500-2000 meals to people. Which is not a terrible lot but when you consider the food that we give away, the energy we save and the community we give. A community to people...to some people who wouldn't have it otherwise. Then it’s good. I mean I think it’s really meaningful.”

Once again, the statement above reiterates that those receiving the meal are not clients, but fulfill a vital role in the exchange process that is taking place. Together FNB volunteers and those receiving the meal, engage in producing an inclusive space, where values such as inclusiveness and community dominate. Homeless individuals and other individuals utilizing the meal serving are not treated as “invisible”, but rather equal partners in the public meal exchange.

\section{Conclusion}

In this chapter I argued that Portland FNB challenges what is considered public space by producing a more just urban landscape. By constructing a space in which food is valued as a human right and all individuals are invited to partake in the production process, Portland FNB further challenges the type of activity that is deemed to be appropriate within public space. Individuals that are typically forbade to utilize public space are welcome and their right to that space is asserted. This claim does not go uncontested from other social actors such as city authorities and private entities. Through regulation, the state of public space becomes volatile as public space is constantly being redefined in relation to actual physical space and the activities regarded to be acceptable within it. Additionally, increased surveillance creates an intimidating urban landscape to 
operate within. These encounters with public peace officers and private security may not completely restrict access to public space, but they do act as another barrier that must be considered.

Despite this resistance, Portland FNB continues to operate "successfully" within the city. Meal servings are the primary way in which Portland FNB attempts to build community and provide healthy and nutritious food to vulnerable populations within Portland. The colonization of space asserts that the "right to the city" is indeed a human right. Individuals not only have the right to collectively share adequate and nutritious meals, but also have the right to collectively produce an urban landscape in which social relations are re-embedded into the city. As cities have become experimental sites for the implementation of neoliberal policies that seek to create a space for the accumulation of capital and elite consumption, it can be argued that neoliberalism has also become "localized". This "localization of neoliberalism" is time and place specific, but nonetheless the mechanisms used to implement neoliberal policies remain similar (Brenner and Theodore 2002:368).

The case of Portland FNB helps to illustrate that as public space is either eliminated completely or subject to increased surveillance, space for elite consumption is simultaneously created. The increased regulation and surveillance of public space by the city also indicates that the state is not directly opposed to the market, but rather the two often work in conjunction with one another. Additionally, Portland FNB directly challenges the slashes in funding for social provisions by distributing meals with no requirement of payment or labor (Brenner and Theodore 2002:369-371). Unlike, a food line or non-profit organization, the colonization of public space by Portland FNB asserts 
that public space is a common good that should not be subject to retraction through regulation or surveillance.

As urban restructuring coincides with the increased regulation of public space, oftentimes marginalized populations are disproportionately targeted for enforcement and pushed to the invisible parts of the city. Portland FNB challenges this geographical displacement, while contesting the creation of more volatile urban landscape. Portland FNB reclaims public space for the collective use of all urban inhabitants. The meal serving is an invitation to participate in socially constructing a more just urban space albeit temporarily. This space reflects the broader dynamics Portland FNB would like to see within implemented within larger society, such as transparency, political participation, equality etc. Through the colonization of public space, Portland FNB reclaims the city as a site for democratic experimentation, not the implementation of neoliberal economic and political policies and attempts to create a more just and equal society at large. 


\section{CHAPTER VI: DISCUSSION AND CONCLUSION}

This study explored and examined the organizational model of Portland FNB and how participants understand it to be an alternative to top-down bureaucratic organizations. The following research questions guided this case study: 1) What is the organizational structure of Portland FNB?, 2) Do Portland FNB respondents understand the organizational structure of FNB to be an alternative organizational model and if so, how?, and 3) How is Portland FNB's use of public space reflective of its organizational dynamics and principles? The organizational model of Portland FNB allows participants to actively engage in a political process that rejects capitalist and bureaucratic rationale. Through the colonization of public space, Portland FNB resists the creation of a privatized/neoliberal urban landscape. As space is increasingly regulated and subject to surveillance, Portland FNB actively reclaims public space as a common good. Through open invitations to participate and the sharing of free meals, Portland FNB constructs a space where survival is a collective effort. In this case the notion of survival is expanded to include political participation. Despite the absence of laws banning the sharing of food in public, Portland FNB continues to face resistance as they colonize public space. By not asking permission, Portland FNB temporarily alters the landscape of the city, demonstrating that a more just and equal society is possible.

In this study, data collected via in-depth interviews, was analyzed and showed that Portland FNB participants understood FNB's structure and goals and their own participation in the SMO. Data collected from participant observation provided insight into the day-to-day functioning of both Portland FNB chapters. These observations illustrated what the primary organizational tasks were, how they were divided and how 
Portland FNB utilizes public space. The use of publicly available online documents, such as the FNB website, specific FNB chapters' websites and FNB chapters' Facebook pages allowed for data triangulation. The publicly available documents aided in the identification of the values and principles, of specific FNB chapters, and provided a general description of the organizational structure of FNB. The following discussion of my findings will address the research questions that I posed at the beginning of the thesis. Although these findings are specific to Portland FNB, the implications of this research likely extend beyond Portland FNB to other challenging organizations, both in terms of organizational structure and the proactive use of public space.

\section{Values Associated With Portland FNB}

Portland FNB respondents often expressed an affinity for anarchist/democratic values. These values include anti-authoritarianism, inclusiveness, transparency and accountability. Inherent within FNB is the rejection of authority. Within Portland, FNB does not seek permission from the city to engage in direct action, thus rejecting formal authority. The process of obtaining permits such as a food handler's license and those allowing for the assembly of a temporary shelter is consciously avoided. This is reflective of grassroots, Do It Yourself culture, as FNB participants take pride in combating food insecurity, absent of collaboration with the state and various mainstream non-profit organizations (Spataro 2014:1-2). Portland FNB rejects “compassionate conservatism”, which stresses the morality of volunteering in faith-based organizations that address social needs, while acknowledging the government is limited in its ability to combat inequality (Tipton 2004:461). Within the context of FNB, the government rather than 
being viewed as limited in its role, is often seen as helping to produce and magnify existing inequality.

The organizational model of Portland FNB is understood by respondents to be radically different in comparison to the state or non-governmental organizations. Through the adoption of anarchist principles Portland FNB attempts to "reinvent democracy" at an organizational level (Graeber 2011). Anarchy is often associated in American’s thinking with chaos, bedlam and disorganization but Portland FNB serves as an example that grassroots participation from the bottom-up can be the foundation of a working, sustained organization (Juris 2009). The organizational structure of Portland FNB is reflective of values and larger principles such as anti-authoritarianism, egalitarianism and transparency.

Within the organization itself, Portland FNB rejects formal positions such as president, vice-president and other offices that characterize top-down power relations (Spataro 2014). This lack of formal leadership suggests an overall preference for political and social equality within the organization which other scholars have noted to characteristic of "new" social movements (Juris 2009; Pickerill 2007). However the lack of identifiable, formal leaders is not the same as a lack of leadership. Organizing horizontally allows participants within Portland FNB to fill leadership roles which they deem appropriate. As leadership is not fixed, all individuals are able to hone leadership skills free from coercion or domination (Fitzgerald and Rodgers 2000). NICE

Individuals that take on added responsibility and accountability in ensuring the meal serving is completed, constitute bottom-liners within the organization. These individuals complete tasks essential to successful meal serving (conducting pick-ups, 
providing cooking supplies, etc.). This illustrates that leadership within Portland FNB stems from assuming tasks without the power associated with a title or formal position (Aminzade et al. 2001). Bottom-liners within Portland FNB, actively disperse knowledge outwards in order to prevent potential hierarchies from forming. In this sense, "openaccess” to leadership is valued over the typical power associated with an office or position.

\section{Structure of Portland FNB}

The anarchist and democratic philosophical underpinnings of FNB influence how Portland FNB is structured. Like NSMs, Portland FNB is a loosely structured, nonhierarchical SMO that practices consensus-based decision making (Buechler 2000; Melucci 1980). At the local level, Portland FNB is indicative of a cultural logic of networking (Juris 2005). Each cell of Portland FNB operates autonomously. However, through transparent communication, participatory democratic decision-making and routine collaboration, the cells constitute a single chapter of FNB. The establishment of horizontal ties helps to ensure that either cell does not assume a position of power or potentially misrepresent the larger principles of FNB. In everyday life, hierarchy must be eliminated, and democracy embraced, in order to successfully prefigure a more equal and just society (Spataro 2014:2). The model of Portland FNB uses is aimed at the creation of a space where individuals can openly practice values in opposition to capitalist and bureaucratic rationale. This space becomes a site for regular experimentation in democracy. Portland FNB challenges other entities within the larger society such as the state and non-profit social service organizations, which are structured-bureaucratically. 
Portland FNB offers individuals the opportunity to routinely engage in a more democratic political process.

Unlike more bureaucratic organizations, Portland FNB must grow outwards at several points rather a single focal point. This ensures that cells remain small enough to practice consensus based decision-making and eliminates the potential for centralization. At the organizational level this helps to prevent situations in which individuals may have to act in opposition to democratic ideals (Fitzgerald and Rodgers 2000). An everexpanding membership base coinciding with centralized authority can result in the formation of bureaucracy and bureaucratic processes in order to manage information, capital, etc. Inevitably this impacts the level of transparency an organization can have, the type of leadership it uses, etc. By remaining decentralized and using little capital, Portland FNB is able to remain horizontally organized, an alternative to top-down organizational models. The structure of Portland FNB itself is a symbolic statement, exemplifying that a more just and equal society is possible.

\section{Strategy and Tactics}

As Portland FNB seeks a more just and equal society, the SMO is focused on radical change rather than reform-oriented efforts. Portland FNB avoids collaborating with the state and non-profit organizations. The SMO does not seek permission to engage in direct action and rather operates outside the existing regulatory framework. Portland FNB routinely engages in direct action by temporarily occupying public space and serving free meals. This effort is sustained and in the long term space is colonized, as Portland FNB asserts that food is a right and not a privilege. By distributing free meals, Portland FNB decommodifies food, extending opposition to the free market as well (Vail 
2010). The distribution of free meals is understood by Portland FNB participants to be inherently different from that of soup kitchens, missions, etc. Portland FNB operates with little financial resources as it does not receive funding from the state or other institutions. Portland FNB's engagement in direct action is indicative of the desired values respondents would like to see instituted and practiced within larger society (Juris 2009). For Portland FNB, the decommodification of food is symbolic of opposition to both the market and further marginalization of vulnerable populations, while the use of public space temporarily democratizes the urban landscape.

\section{The Use of Public Space in Prefiguring Society}

As public space is increasingly regulated and subject to surveillance, the urban landscape is becoming progressively more unstable. Additionally, local ordinances regarding the use of public space are greatly reducing access to it and completely eliminating access for some populations. The disappearance of public space coincides with the creation of space for elite consumption, as cities have become sites for neoliberal experimentation (Brenner and Theodore 2002). Through the colonization of public space Portland FNB directly opposes both neoliberal ideology and the contradictory forms it takes when policies are implemented at the local level. The occupation of public space by Portland FNB, is prefigurative as public space would ideally be used collectively, in meeting social needs.

Portland FNB not only reclaims public space as a common good but also asserts that undertaking life-sustaining activities in public space is a human right. The urban landscape is temporarily altered as a more democratic space is carved out within the city. Marginalized populations such as the homeless are most visibly affected by the 
contraction and increased regulation of public space. The restriction of activities for survival such as sleeping, eating, etc. further privatize the day-to-day life of marginalized populations, as individuals are pushed to the backdrop of urban life. Portland FNB reasserts that the city is a site for the production of social relations not for the accumulation of capital or elite consumption practices. The colonization of public space by Portland FNB creates a space that could be considered an "autonomous geography”. Autonomous geographies are defined as "spaces where people desire to constitute noncapitalist, egalitarian and solidaristic forms of political, social, and economic organization through a combination of resistance and creation.” (Pickerill and Chatterton 2006:730). I wonder whether occupation is a better word than colonization (which for me is a word of the powerful)

By engaging in direct action, Portland FNB resists the increased regulation and surveillance of public space while creating a space that emphasizes egalitarian relationships and more collective forms of economic exchange. The word "autonomous" is misleading however as Portland FNB cannot create a completely autonomous space nor can it operate completely autonomously. As cities have become sites for the neoliberal experimentation, organizations such as Portland FNB must operate alongside the state and ongoing capitalist development (Böhm et al. 2010). The resistance Portland FNB experiences in colonizing public space helps to illustrate the interstitial existence of the SMO. Not only must Portland FNB interact with various social actors, the SMO must also navigate the physical space, as public space is often located within a fractured landscape of ownership. 
Portland FNB relies on having access public space in order to effectively engage in direct action. As public space faces the constant threat of retraction, the ability to participate in alternative organizational models and engage in collective action is diminished. The case of Portland FNB is illustrative of the continual defining and redefining of what and who is considered to be public. Portland FNB's definition of public is vastly different from the state and other institutions. It contends the public is all individuals and public space to be accessible for collective use and the production of more egalitarian social relations. As useable public space is often nearly completely enclosed or surrounded, the attempt to use, manipulate and transform space is inherently contentious as illustrated by the experiences of Portland FNB.

\section{Implications}

This case study of Portland FNB contributes to the body of literature on social movement theory and social movements in multiple ways. Portland FNB serves as an empirical example of an anarchist social movement, providing insight into the structure of more radical social movement organizations, adding to the bodies of knowledge that already exist. As neoliberal economic and political policies are implemented at various scales (global, national and level) both the economic and political landscape are becoming increasingly tumultuous. As neoliberal policies result in geographies developing unevenly across space and time, a more adaptive approach to resisting these processes may be needed.

New social movements have been characterized as holding the "belief that everyday life is political” (Buechler 2000). This case highlights how beliefs and values shape organizational structure. By eliminating hierarchy and embracing democracy at a 
structural level, Portland FNB participants, take the initial steps in creating a more just and equal society. Portland FNB suggests that organizing horizontally is not only illustrative of a preference for more egalitarian political and social relations but also results in the creation of a space for democratic experimentation. An affinity for antiauthoritarianism, direct democracy and transparency, coincides with structural characteristics such as a decentralized network, the use of consensus based decisionmaking and the lack of formal leadership. The day-to-day operation of Portland FNB provides numerous opportunities for individuals to engage in an organization with the characteristics listed above. Portland FNB should serve as an example to other organizations and institutions looking to democratize. Portland FNB exemplifies a variety of ways in which this could done such as the extension of leadership opportunities to a wider range of individuals, engaging in transparent communication, etc.

Hierarchical organizations assign leadership roles based on depth of knowledge or skills that were previously attained. In FNB, the dispersion of both knowledge and skills along with the lack of top-down power relations allows all individuals to engage in leadership roles if so desired. Although the level of effectiveness cannot be directly measured, Portland FNB does demonstrate that horizontality tends to become leader-full not leaderless thus increasing the scope of what constitutes as participation.

Portland FNB illustrates that being leaderless in formal terms may have some functional benefit for SMOs. As the environment in which SMOs operate is increasingly regulated and ever-changing, a more dynamic structure may increase adaptability. The ability for all participants to fill leadership roles and make integral decisions is an organizational response to a volatile environment. This case study illustrates that 
leadership does indeed exist within horizontally structured social movements though in a drastically different form. This study helps add to the need for more scholarly attention on leadership in explicitly non-hierarchical SMOs. In contrast to neoliberal political and economic policies, the organizational model of Portland FNB provides a stark alternative to more disengaged political forms. This case study illustrates that "new" social movements can be sites for experiments in democracy.

Because Portland FNB relies on engaging in direct action, over a sustained period of time, directing attention to inequality, its success cannot be gauged by obtaining vast resources or taking advantage of political opportunities and therefore deviates from foundational social movement literature. In the context of Portland FNB, success is defined by the ability to sustain weekly meal servings, thereby continuing to serve as an example of a more just and equal way to organize and operate. The ability of Portland FNB participants to be flexible and adaptable, ensures the organization can adequately respond to moments of neoliberal "destruction" and "creation" and the immediate effects of localized neoliberalism.

The experience of Portland FNB within the city indicates that the status of public space is one of continual contestation. The increased regulation and surveillance of public space restricts how it can used and who can use it. The ability of SMOs to engage in direct action often hinges on being able to access public space. Social movements such as Occupy and the more recent protests in Hong Kong are examples that help illustrate this. The proactive occupation of public space allows for economic and political grievances and demands to be collectively communicated. Although, the occupation of public space may be eventually disrupted, the visibility of such actions and processes associated with 
organizing them can have lasting effects. As public space is continually defined and redefined, SMOs may continually have to engage with the state and private entities in order to retain access.

In order to effectively operate within a controlled landscape, SMOs may adopt a more loosely structured organizational model similar to Portland FNB in order to increase adaptability. The temporary transformation of public space by Portland FNB alters the urban environment and makes the urban landscape more livable. This strategy of temporary occupation, coinciding with a life-sustaining activity could be adopted by other SMs and SMOs whose goal is to resist and mediate the negative effects of neoliberal economic and political policies.

Within Portland, public space is increasingly regulated, hindering the ability to access and effectively use it. Space is divvied up by local government and private entities. This creates pockets of occupiable space within space that is regarded as "offlimits". While the loss of public space may be just one of the many "destructive moments” (Brenner and Theodore 2002) of localized neoliberal policies, Portland FNB demonstrates that the retraction of public space can successfully be resisted. By not seeking permission to utilize public space and serve free meals, Portland FNB is able to operate outside the existing regulatory framework to some degree.

The longevity of Portland FNB and FNB as whole, illustrates that operating with a set of oppositional values is possible in the long term. Horizontality can be a sustainable and effective manner in which to organize. Without centralized and formal authority, organizations can make it increasingly difficult for authorities to regulate their activity. The affinity for DIY culture within Portland FNB illustrates that the right to the city can 
be asserted within the context of everyday life. The elimination of hierarchy and the embracement of democracy can temporarily extend to the physical landscape, illustrating that urban life can be organized in a manner that repudiates the notion of cities as sites for capitalist accumulation or elite consumption. The alteration of the urban landscape asserts that collectively participating in and producing urban life is a human right. Although this alteration of urban space is temporary, it serves as a symbolic gesture, demonstrating that a more just and equal society is possible.

\section{Conclusion}

\section{Limitations}

The Portland chapter of FNB is one of many chapters scattered throughout the globe. Staying true to FNB's principle of decentralization, the Portland chapter operates autonomously while affiliating itself with the larger SMO. With this in mind, it must recognized that the findings of this study are specific to the Portland chapter of FNB and not generalizable to all FNB chapters. It is quite possible that the Portland FNB chapter operates profoundly different than other FNB chapters and is an exceptional case. The Portland chapter is a very small, close-knit organization. Table 1 . indicates that interviewees are quite racially/ethnically homogenous in addition to sharing other similar characteristics such as level of education, etc. These demographic characteristics of interviewees are reflective of the lack of racial/ethnic diversity within the Portland metropolitan area. In other locations, FNB chapters may be more diverse not only in terms of who participates but also in terms of adopting a more broad approach to social justice. 
The recruitment of interviewees relied heavily on snowball sampling. The limited number of those heavily involved in Portland FNB greatly constricted the number of possible interviewees. However, the eight interviewees currently involved make up the majority of regular FNB participants which gives me confidence that my research captures the core of Portland FNB. The relatively personal relationships between these individuals may have affected the amount or the depth of information they were willing to share with me. The ever-changing composition of Portland FNB made it difficult to recruit more interviewees as several had ceased to be involved with the organization before I entered the field. These individuals were difficult to locate as current participants often did not know how to get in contact them. In larger urban areas, it can be assumed that FNB chapters are larger.

Suggestions for Future Research

There are several suggestions for future research that would help add to the academic discourse in ways that this limited study of Portland FNB cannot. First, future studies could strive to include the experience of various FNB chapters. As previously mentioned, other FNB chapters may be larger and more diverse in terms of participation. This would provide an opportunity to more closely examine how horizontally organizing manifests when the number of participants is potentially larger. It could also shed light on the effectiveness of horizontality in resisting the reproduction of other forms of oppression such as racism, etc.

A second possibility for future research is conducting a comparative study of horizontally structured SMOs. FNB is not the only horizontally structured SMO. Potential cases include Occupy, Black Lives Matter and a multitude of other grassroots 
organizations. This would allow for a more nuanced analysis of organizational structure and practices that reflect values of democracy, transparency and egalitarianism. As a single case, Portland FNB cannot provide a comprehensive analysis of what it means to organize horizontally.

My third and final recommendation for future research would be a study focusing on how public space is manipulated and contested by various social actors. As public space increasingly shrinks in the wake of neoliberal policy, the ability to live within an urban environment has become more difficult. The right to move through, occupy, and transform space has all but disappeared in some cases. Future research should focus on the processes of reclaiming public space for public use such as the experience of homeless populations or the use of public space for leisure activities such as skateboarding. A broader study would further shed light on how public space is constrained differently, depending on time and place and the different forms resistance to it may take. 


\section{REFERENCES}

2013 Point-In-Time: Count of Homelessness in Portland/Multnomah County, Oregon. 2013. https://www.portlandoregon.gov/phb/article/513379.

Alkon, Alison Hope. 2012. Black, White, and Green: Farmers Markets, Race, and the Green Economy. Athens, GA and London, UK: The University of Georgia Press

Alkon, Alison Hope, and Agyeman, Julian. 2011. "Introduction: The Food Movement as Polyculture.” Pp. 1-20 in Cultivating Food Justice: Race, Class, and Sustainability, edited by Alison Hope Alkon and Julian Agyeman. Cambridge, MA: MIT Press.

Aminzade, Ron, Jack Goldstone, and Elizabeth Perry. 2001. "Leadership Dynamics and the Dynamics of Contention.” Pp. 126-154. Silence and Voice in the Study of Contentious Politics, edited by Doug McAdam, Sidney Tarrow and Charles Tilly. Cambridge: Cambridge University Press.

Barron, James and Colin Moynihan. 2011. "City Reopens Park After Protestors Are Evicted.” The New York Times. http://www.nytimes.com/2011/11/16/nyregion/pol ice-begin-clearing-zuccotti-park-of-protesters.html?_r=0.

Barszewski, Larry. 2015. "Food Not Bombs sues Fort Lauderdale Over Homeless Feeding Rules.” Sun Sentinel. http://www.sun-sentinel.com/local/broward/fortlauderdale/fl- lauderdale-new-homeless-lawsuit-20150129-story.html.

Baxter, Pamela and Susan Jack. 2008. "Qualitative Case Study Methodology: Study Design and Implementation for Novice Researchers.” The Qualitative Report 13(4):544-559.

Böhm,Steffen, Ana C. Dinerstein and André Spicer. 2010. “(Im)possibilities of Autonomy: Social Movements in and Beyond Capital, the State and Development.” Social Movement Studies 9(1):17-32.

Breines, Wini. 1989. Community and Organization in the New Left 1962-1968: The Great Refusal. New Brunswick, New Jersey: Rutgers University Press.

Brenner, Neil and Nik Theodore. 2002. "Cities and the Geographies of 'Actually Existing Neoliberalism.”” Antipode 34(3):349-379.

Buechler, Steven M. 2000. Social Movements in Advanced Capitalism. New York and Oxford: Oxford University Press.

Butler, C.T. Lawrence and Keith McHenry. 1992. Food Not Bombs. Montpelier, Vermont: Capital City Press. 
Carroll, William K. and R.S. Ratner. "Master Framing and Cross-Movement Networking in Contemporary Social Movements.” 1996. The Sociological Quarterly 37(4):601-625.

Castells, Manuel. 1983. The City and the Grassroots: A Cross-Cultural Theory of Urban Social Movements. University of California Press.

Charmaz, Kathy. 2006. Constructing Grounded Theory: A Practical Guide Through Qualitative Analysis. Thousand Oaks, CA: Sage.

Clemens, Elisabeth S. and Debra C. Minkoff. 2004. "Beyond the Iron Law: Rethinking the Place of Organizations in Social Movement Research.” Pp. 155-170 in The Blackwell Companion to Social Movements edited by David A. Snow, Sarah A. Soule and Hanspeter Kriesi. Malden, MA: Blackwell Publishing.

Dellacioppa, Kara, Sergio Soto and Alan Meyer. 2013. "Rethinking Resistance and the Cultural Politics of Occupy.” New Political Science 35(3):403-416.

Evans, S.M. and H. Boyte. 1986. Free Spaces: The Sources of Democratic Change in America. New York: Harper and Row.

Fitzgerald, Kathleen J. and Diane M. Rodgers. 2000. "Radical Social Movement Organizations: A Theoretical Model.” The Sociological Quarterly 41(4):573-592.

Food Not Bombs. Frequently Asked Questions. http://www.foodnotbombs.net/faq.html.

Food Not Bombs-Seattle. http://www.scn.org/foodnotbombs/.

Food Not Bombs-Southampton. https://sotonfoodnotbombs.wordpress.com/.

Forelle, Charles, Nektaria Stamouli and Alkman Granitsas. 2015. "Syriza Win in Greek Election Sets Up New Europe Clash.” The Wall Street Journal. http://www.wsj.com/articles/syriza-win-in-greek-election-sets-up-new-europeclash-1422168982.

Gamson, Josh. 1989. "Silence, Death and the Invisible Enemy: AIDS Activism and Social Movement 'Newness'.” Social Problems 36(4):351-367.

Graeber, David. 2002. “The New Anarchists.” New Left Review 13:1-13.

Griffin, Anna. 2015. “Our Homeless Crisis.” The Oregonian, January 17. Retrieved April $12^{\text {th }}$, 2015. http://www.oregonlive.com/portland-homeless/.

Harvey, David. 2012. Rebel Cities: From the Right to the City to the Urban Revolution. London, UK and Brooklyn, NY: Verso.

Harvey, David. 2005. A Brief History of Neoliberalism. Oxford: Oxford University Press.

Harvey, David. 2003. “The Right to the City.” International Journal of Urban and Regional Research 27(4):939-941. 
Heynen, Nik. 2010. "Cooking up Non-violent Civil-disobedient Direct Action for the Hungry: 'Food Not Bombs' and the Resurgence of Radical Democracy in the U.S." Urban Studies 47:1225-1240.

Hodkinson, Stuart and Paul Chatterton. 2006. "Autonomy in the city?: reflections on the social centres movement in the U.K.” City: Analysis of urban trends, culture, theory, policy, action 3(10):305-315.

Juris, Jeffrey. 2012. "Reflections on \#Occupy Everywhere: Social media, public space, and emerging logics of aggregation.” American Ethnologist 39(2):259-279.

Juris, Jeffrey. 2009. “Anarchism, or the cultural logic of networking.” Pp. 215-223 in Contemporary Anarchist Studies: An Introductory Anthology of Anarchy in the Academy, edited by Randall Amster, Abraham DeLeon, Luis Fernandez, Anthony J. Nocella II and Deric Shannon. New York, NY: Routledge.

Juris, Jeffrey. 2005a. "Networked social movements:global movements for global justice.” Pp. 341-362 in The Network Society: A Cross-Cultural Perspective, edited by Manuel Castells. Cheltenham, UK and Northampton, MA: Elgar Publishing.

Juris, Jeffrey. 2005b. "Social forums and their margins: Networking logics and the cultural politics of autonomous space.” Ephemera 5(2):253-272.

Lefebvre, Henri. 1996. “The Right to the City.” Pp. 147-159 in Writings on Cities, edited by Eleonore Kofman and Elizabeth Lebas. Malden, MA: Blackwell Publishers Inc.

Marcuse, Peter. 2009. "From critical urban theory to the right of the city." City 13(23):185-196.

Mares, Teresa M. and Devon G. Peña. "Environmental and Food Justice: Toward Local, Slow and Deep Food Systems.” Pp. 197-220 in Cultivating Food Justice: Race, Class, and Sustainability, edited by Alison Hope Alkon and Julian Agyeman. Cambridge, MA: MIT Press.

Marshall, Catherine and Gretchen B. Rossman. 2010. Designing Qualitative Research: Fifth Edition. SAGE Publications, Inc.

McCarthy, John D., and Mayer N. Zald. 1977. "Resource Mobilization and Social Movements: A Partial Theory.” American Journal of Sociology 82(6):1212-1241.

McCutcheon, Priscilla. “Community Food Security 'For Us, By Us': The Nation of Islam and the Pan African Orthodox Christian Church.” Pp. 177-196 in Cultivating Food Justice: Race, Class, and Sustainability, edited by Alison Hope Alkon and Julian Agyeman. Cambridge, MA: MIT Press. 
Melucci, Alberto. 1980. “The New Social Movements: A Theoretical Approach.” Social Science Information 19(2):199-226.

Mitchell, Don and Nik Heynen. 2009. "The Geography of Survival and the Right to the City: Speculations on Surveillance, Legal Innovation, and the Criminalization of Intervention.” Urban Geography 30(6):611-632.

National Coalition for the Homeless. 2014. "The Criminalization of Efforts to Feed People in Need.” http://nationalhomeless.org/wp-content/uploads/2014/10/FoodSharing2014.pdf.

Nicholls, Walter J. and Justin R. Beaumont. 2004. “The Urbanisation of Justice Movements: Possibilities and Constraints for the City as a Place of Contentious Struggle.” Space and Polity 8(2):119-135.

Olson, Mancur. 1965. The Logic of Collective Action: Public Goods and the Theory of Groups. Cambridge, MA: Harvard University Press.

Pickard, Victor W. 2006. "United yet autonomous: Indymedia and the struggle to sustain a radical democratic network.” Media, Culture and Society 28(3):315-336.

Pickerill, Jenny. 2007. “'Autonomous online’: Indymedia and practices of alterglobalisation.” Environment and Planning 39:2668-2684.

Pickerill, Jenny and Paul Chatterton. 2006. "Notes towards autonomous geographies: creation, resistance and self-management as survival tactics.” Progress in Human Geography 30(6):730-746.

Pittsburgh Food Not Bombs. http://www.fnb-pittsburgh.org/index171c.html?page=about.

Polletta, Francesca. 1999. “'Free spaces’ within collective action.” Theory and Society 28:1-38.

Portland Parks and Recreation. http://www.portlandoregon.gov/parks/finder/index.cfm?a ction= ViewPark\&PropertyID=12.

Purcell, Mark. 2002. "Excavating Lefebvre: The right to the city and its urban politics of the inhabitant." GeoJournal 58:99-108.

Purcell, Mark. 2014. "Possible Worlds: Henri Lefebvre and the right to the city.” Journal of Urban Affairs 36(1):141-154.

Resnikoff, Ned. 2014. "Hunger and Homelessness Rise in Several U.S. Cities.” http://america.aljazeera.com/articles/2014/12/11/hunger-and-homelessnessriseinse veraluscities.html

Routledge, Paul. 2003. "Convergence space: process geographies of grassroots globalization networks." Transactions of the Institute of British Geographers 28(3):333-348. 
Shiva, Vandava. 2002. Water Wars. Cambridge, MA: South End Press.

Spataro, David. 2014. “Food Not Bombs.” Encyclopedia of Food and Agricultural Ethics: 1-8.

Stobart, Luke. 2014. Whatever happened to the Indignados? 1: Radical struggle. http://left-flank.org/2014/03/17/whatever-happened-indignados-part1/\#sthash.3JXIgNON.dpuf

Taylor, Verta and Nella Van Dyke. 2004. “'Get up, Stand Up’: Tactical Repertoires of Social Movements.” Pp. 262-293 in The Blackwell Companion to Social Movements edited by David A. Snow, Sarah A. Soule and Hanspeter Kriesi. Malden, MA: Blackwell Publishing.

Tipton, Steven M. 2004. Rev. of Heaven's Kitchen: Living Religion at God's Love We Deliver, by Courtney Bender. Contemporary Sociology 33(4):460-462.

U.S. Census Bureau: State and County Quick Facts. http://quickfacts.census.gov/qfd/states/41/4159000.html.

Vail, John. 2010. "Decommodification and Egalitarian Political Economy.” Politics and Society 38(3):310-346.

VanderHart, Dirk. 2013. "Storm the Gates: A Fight's Brewing in Colonel Summers Park.” The Portland Mercury. http://www.portlandmercury.com/portland/stormthe-gates/Content?oid=9913697. 


\section{APPENDIX}

\section{Appendix: Interview Guide for Portland FNB Participants}

\section{1) Background}

a. Why/How did you become involved with Food Not Bombs?

b. Have you been involved with Food Not Bombs in any other geographic location?

c. Other than Food Not Bombs, have you been and/or are you currently involved with other organizations? If so, which ones?

d. In what capacity have you been involved with Food Not Bombs? For how long?

2) Organizational Goals \& Structure

a. What do you feel the organization's goals are?

i. How effective do you feel the organization is in achieving these goals?

ii. What do you think are the barriers to achieving these goals?

b. Why is direct action in the form of serving meals desirable? What does this signify?

c. How would you describe the structure of the organization?

i. What are some positive characteristics of this structure? What are some negatives?

3) Understanding of the Organization

a. How are decisions made within the organization?

i. What are the positive and negative aspects of this decision-making process?

b. How does Food Not Bombs gain access to resources that are difficult to obtain (food, space, etc.)?

c. How has FNB come to use the space it currently utilizes? What issues have arisen from this usage?

4) Future

a. What impact do you believe your participation with Food Not Bombs is having?

b. What impact would you like it to have? 
5) Demographic Questions

a. What is your age?

b. Please describe your gender.

c. Please describe your race/ethnicity.

d. Please describe your level of education.

e. Are you currently employed? Where do you work?

f. Do you currently live in the Portland metro area? How long have you resided in the Portland metro area? 